LEAD AND ZINC DEPOSITS OF IOWA. BY

A. G. LEONARD. 



\section{LEAD AND ZINC DEPOSITS OF IOWA.}

BY A. G. LEONARD.

PAGE

Chief sources of the world's supply of lead and zinc.................. 13

History of lead and zinc mining in Iowa ....... 14

Upper Mississippi lead and zinc region

Limits and extent of the area ......

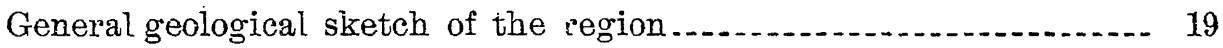

Principal formations............... 20

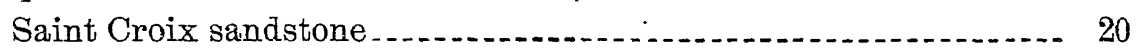

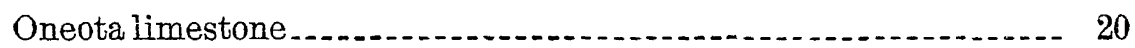

Saint Peter sandstone........................................ 21

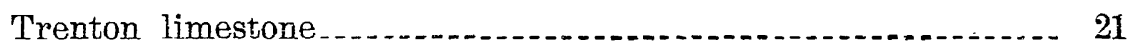

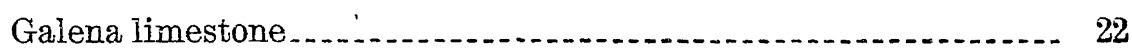

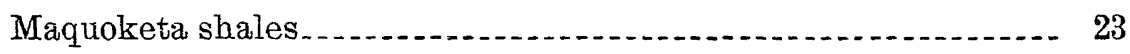

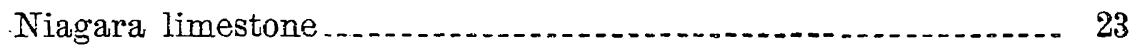

Mode of occurrence of lead and zine deposits .

Ore deposits usually in areas of disturbance..................... 23

Iowa deposits an exception _.....

Lead and zinc deposits mostly. in limestone ....................... 2 t

Comparison of Upper Mississippi mines with Missouri region........ 25

Lead and zinc ores and associated minerals

Lead minerals ........... 25

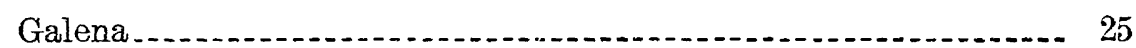

Cerussite ............. 26

Zine minerals ....

Smithsonite........

Sphalerite _. 
Associated minerals $\quad$ PAGE

Pyrite and Marcasite......................................... 28

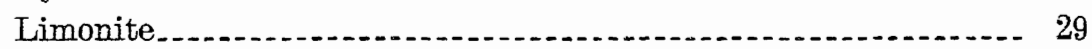

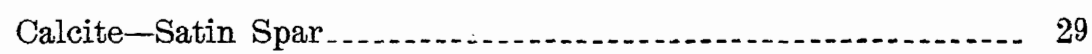

Gypsum

Dolomite................ 36

Mode of occurremee of the Iowa ores _

The crevices............. 36

Direction, extent, "openings"

Mode of occurrence in the crevices .................... 38

(1) As a vertical sheet............................. 41

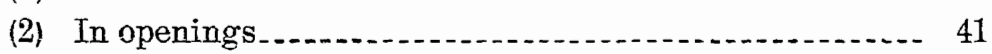

Vertical distribution of lead and zinc _.................... 43

Special description of the mines....

Dubuque county mines..............

Clayton county mines.

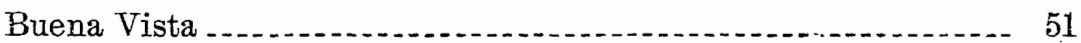

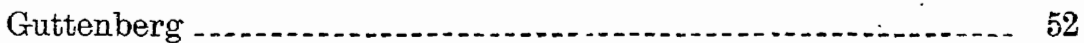

Allamakee county mines ...

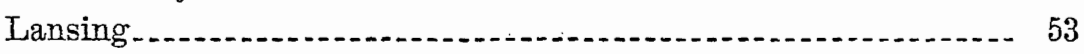

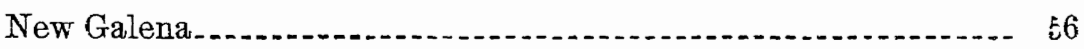

Origin of the deposits

(1) Original source of the lead and zinc.

(2) Localization of the deposits. .......... 58

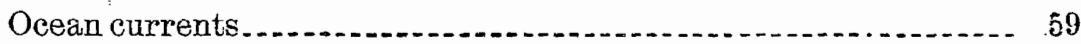

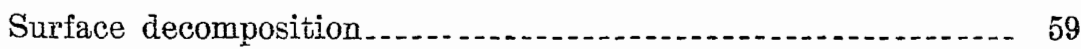

(a) Formation of the crevices _. 61

(4) Filling of the crevices............. 62

Different views as to origin of ore deposits in general ........ 62

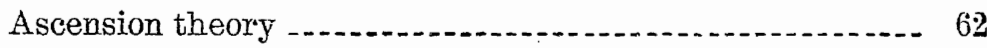

Lateral secretion theory

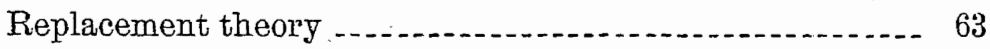

Objections to ascension theory for Iowa deposits .............. 63

Proofs of origin by lateral secretion......................... 61

General methods of working the mines ......

Statistics. - 


\section{CHIEF SOURCES OF THE WORLD'S SUPPLY OF LEAD AND ZINC.}

Lead and zinc are widely distributed over the globe, nearly every inhabited country producing both in greater or less quantity. A complete list of all the countries where these are found would, therefore, be a long one. In the following summary the attempt has been made to mention only the more productive regions; those containing extensive deposits of lead and zinc. The facts have been recently collected by Winslow in his late report on the Missouri deposits."

German Empire.-The zinc ore production of Germany during the past ten years has varied from one-half to threefourths of the production of all Europe, averaging 800,000 tons annually. The lead output has not been so large. The great zinc producing region of Germany is Upper Silesia, which has yielded nearly three-fourths of the total amount. Next in order of importance are the Rhine provinces, Westphalia and Nassau. In lead production the Rhine provinces rank first, and then come Harz, Silesia, Saxony and Nassau.

Spain.-This country ranks far ahead of any other in Europe in the production of lead, and is third during recent years in the output of zinc. The principal lead ore deposits are at Linares and Cartagena; the zinc ores are chiefly from Santander. With the possible exception of the Broken Hill mine in New South Wales, the Linares mines rank first in the world as lead producers. In 1892 they yielded 128,000 tons.

Austria.-Both lead and zinc are here mined in large quantities.

Belgium.-The principal deposits are the Bleiberg lead mines and the Vieille Montagne zinc mines.

Great Britcin.-The most important deposits are in the north of England lead district, which includes the counties of Durham, Northumberland, Cumberland, Westmoreland and Yorkshire.

Greece.-The chief mines are those of Laurium.

*Missouri Geol. Surr., vols. VI and VII. Jefferson City, 1894. 
Italy.-This country is an important zinc producer, and the yield of lead is large. The great bulk of the ore comes from Sardinia.

Russia, France and Sroeden should also be mentioned as producing considerable quantities of lead and zinc.

New South Wales. - The Broken Hill mines are at present the largest producers of lead in the world. They were discovered in 1883, and in 1890 yielded 222,000 tons of ore.

United States. - The ores of lead and zinc occur to a greater or less extent in nearly every state; but in only a dozen or fifteen is lead produced in large amounts, and not more than eight rank as zinc producers. A large proportion of the lead comes from the Rocky Mountain and Great Basin regions. During the last twenty years over three-fourths of the total lead production of the country has been supplied from the western states and territories. These ores are argentiferous, and are mined not so much for their lead as for the gold and silver they contain. The following is a list of states that rank as lead producers: Colorado, Missouri, New Mexico, Utah, Nevada, Arizona, California, Idaho, Montana, Wisconsin and Kansas. Colorado leads in the output of lead, and is closely followed by Missouri. Illinois and Iowa produce small quantities.

The zinc producing states are Missouri, New Jersey, Wisconsin, Kansas, Illinois and Iowa. Missouri stands far ahead of any of the rest, showing a product of 108,000 tons for 1893 . Iowa's production of zine has rapidly increased of late years while its lead output has decreased. In bulletin 80 of the eleventh census, Iowa is credited with the production of 450 tons of zinc during 1889 whereas in the previous report no mention of the zinc output was made.

HISTORY OF LEAD AND ZINC MINING IN IOWA.

It is now nearly two hundred years since the white man discovered lead in the Upper Mississippi region. In 1700 the French explorer Le Sueur made an expedition up the great river from New Orleans in search of ores. He ascended as 
far as the Saint Peters river, now the Minnesota, and it is generally supposed, observed lead at several points along the "Father of Waters." It is interesting to note that as long ago as 1752 the lead region of the Upper Mississippi was located on a map published during that year by Philippe Bauche.* The mines are also mentioned briefiy in an article by M. Guettard in the same volume, pp. 189-220, where they are described as being very rich.

In 1788 the first mining was done within the territory of what is now the state of Iowa. In that year'Julien Dubuque, a native of Canada, obtained from the Sacs and Foxes a grant or lease of land for mining purposes. His claim included seven leagues on the west bank of the Mississippi, from the mouth of the Little Maquoketa to the Tete des Morts and three leagues deep. The area includes most of the productive crevices of Dubuque county. Lead is reported to have been discovered here seven years previously by the wife of Peosa Fox. Dubuque at once took possession of his claim and began mining operations. The place became known as "Spanish Mines" or more commonly as Dubuque's Lead mines. In 1796 he petitioned Carondelet, the Spanish governor of Louisiana, that the tract be granted him by patent from the Spanish government. His request was allowed and was subsequently confirmed by the board of land commissioners of Louisiana. Dubuque continued to develop his prospects until his death in 1810 .

It was twenty years later however, before the mines of the state began to be actively developed. During 1830 several miners from Galena, influenced by the reports they had heard of the Dubuque region, crossed the river and obtaining the consent of the Indians commenced work where the city now stands. One of the first to be opened was the Langworthy crevice on Eagle Point avenue.

But the land on the west of the Mississippi, though it had come under the control of the United States by the Louisiana

*Histoire le L' Academie Royale des Sciences. 1752. 
purchase still belonged to the Indians, and the government, to keep the treaty with them soon ordered the miners to leave and subsequently sent troops from Prairie du Chien to enforce the order.

Two years later, at the close of the Black Hawk war, the large tract known as the Black Hawk purchase, including onethird of the present area of Iowa; was ceded to the United States by the Sacs and Foxes. After the completion of the treaty negotiations the miners again crossed over into the much coveted region where they built cabins and commenced to take out much ore. But a second time they were forced to leave because the treaty had not been ratified. In June, 1833, the treaty went into effeet and the way was at length clear for settlers to take possession of the land. During the next few years large numbers flocked in; prospecting was actively carried on and many mines were soon in operation.

A superintendent of mines was appointed by the government and a system of permits to miners and smeiters was adopted. For some years the smelters were required to pay 6 per cent of all the lead produced. This tax was the cause of much dissatisfaction and was abolished at the end of ten years.

The first "legislation" in Iowa dates from 1830. In June of that year a number of miners met on the banks-of the Mississippi and enacted regulations to govern them in their relations to each other. One of the articles was that "every main shall hold 200 yards square of ground by working said ground one day in six." The most productive period of the Dubuque mines was probably during the years 1835 to 1849 . No record was kept of the amount produced nor can this now be accurately ascertained. Owen" gives the output for 1839 as over $3,000,000$ pounds. In $18548,770,000$ pounds of lead were exported from Dubuque.

Furnaces were early established for smelting purposes. The first contrirance employed. was the primitive one of the

*Ex. Doc., 1st Sess., 26 Cong., vol VI, 39-4J. 


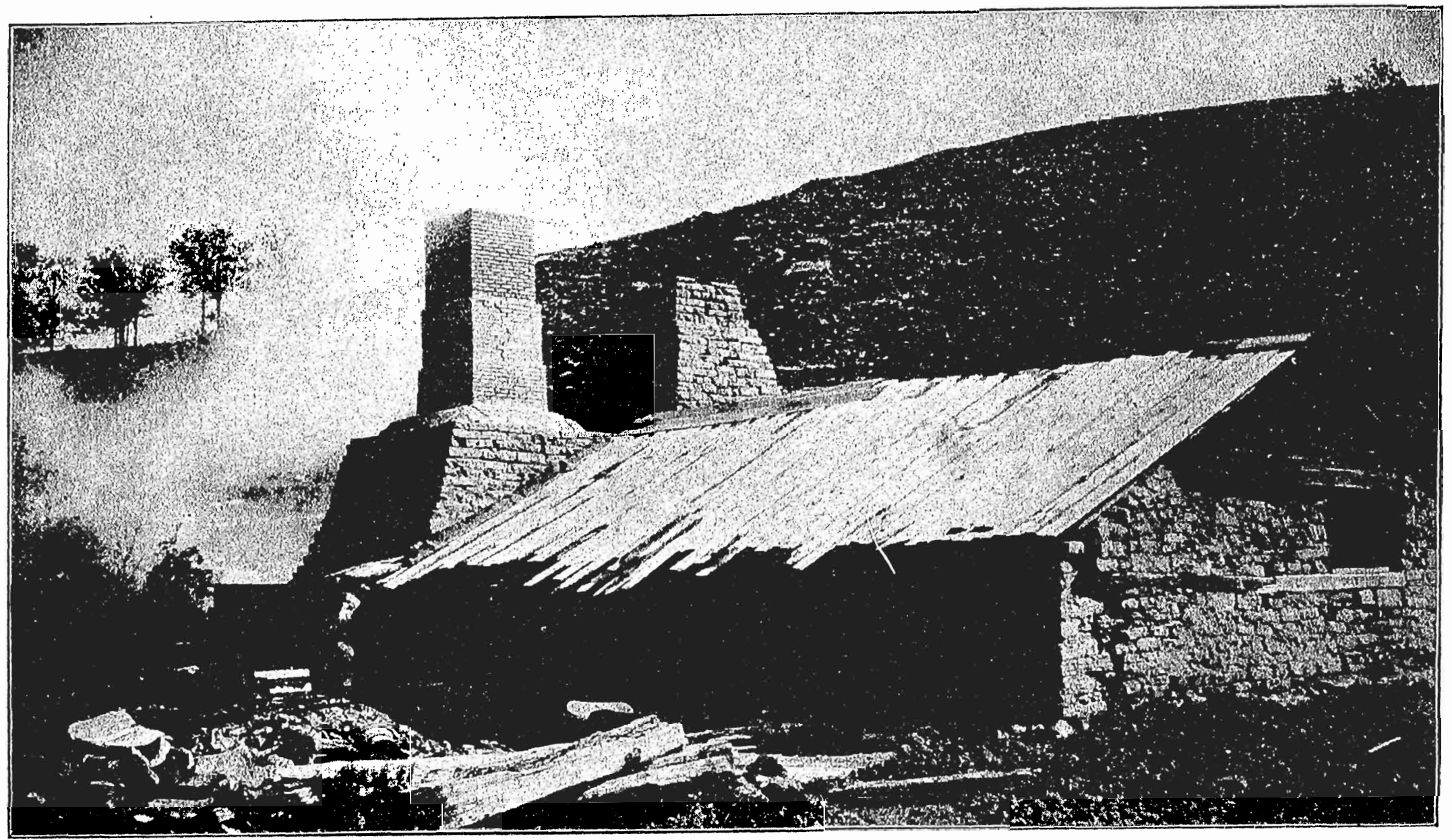

WATER'S LEAD FURNACE, NEAR DUBUQUE. 

Indians, though on a larger scale. A foundation or platform of rock was built about fifteen feet square, the cracks between the stones being carefully filled, and the platform made to slope towards the center. A layer of logs was placed on the rude hearth thus constructed, then a layer of ore and so on alternately until there was enough for the blast. The wood was then fired and the pile allowed to burn down. The metal as it melted sought the lower part of the platform, where it was drawn off from time to time. This process was very wasteful, as besides consuming great quantities of timber it secured less than 50 per cent of the lead. The rich slag thus left behind was eagerly sought in later years.

The next method of smelting employed was what is known as the cupola furnace, a great improvement over the former system, since by its use 65 to 70 per cent of the lead was obtained. In 1834 Peter Lorimier built one of these furnaces at the mouth of Catfish creek; this being the first of the kind in the state. The next year two others were constructed, one on the Little Maquoketa and another in the city of Dubuque. But it still remained true that quite a large per cent of mineral was not extracted and this loss brought about the adoption of the hearth furnace. The first one of these erected in America for smelting lead ore was built in Wisconsin in 1835 about midway between Dubuque and Mineral Pcint. The second in the country, and the first in Iowa, was located on Catfish creek just above Rockdale in Dubuque county. This furnace, which has played an important part in the mining industry of the state, has been in operation more or less since its establishment and it is still running. [See plate i.]

With the hearth furnace practically all of the lead is extracted from the ore and hence it is so much superior to the earlier processes employed that it soon replaced them. There weré several of these furnaces in the vicinity of Dubuque. Besides the one already mentioned, may be named Mr. Brunskill's, on Catfish creek near Center Grove, and Nathan Simpson's, not far northeast of Dubuque. 
It was not until 1860 that zinc came into the market and since then the production of this kindred metal has rapidly increased. During the ten years previous to 1882 the output of zinc more than doubled that of lead, while in 1889, according to the last federal census, the production was 13 to 1 for the entire region.

The principal ore of zinc now shipped from the Iowa mines is the carbonate, or "dry bone" of the miners. Until some thirteen years ago this material was regarded as worthless and was thrown away on the dump piles, or the workings were abandoned when it appeared.

In the fall of 1880 two wagon loads were taken to Benton, Wisconsin, and sold for $\$ 16$ a ton. So far as known, this was the first zinc ore marketed from the mines of the state, and from this time on the carbonate has been removed.in rapidly increasing amounts. The first mine to be worked for zinc was the McNulty (often called the Avenue Top) at the head of Julien avenue, Dubuque. This had previously been operated for lead and $\$ 25,000$ worth is said to have been taken from it. The galena gave out in the crevices and a short distance beyond the zinc carbonate began to appear. It is estimated that this mine has yielded not less than $\$ \tilde{0} 0,000$ worth of zinc. After the sale of the first dry bone many began at once to search for it, and numerous mines were soon being operated. Old lead diggings that had been abandoned when the associated metal began to appear, were again opened up and worked.

\section{UPPER MISSISSIPPI LEAD AND ZINC REGION.}

The lead and zinc region of the Upper Mississippi includes an area having a length east and west of ninety-six miles and a wiath north and south of fifty miles. It embraces the southwest portion of Wisconsin, the northwest corner of Illinois and the adjoining portion of Iowa, comprising within its limits some 3,000 square miles, an area nearly equal to that of Connecticut. The entire region is included in what is 
known as the driftless area. On all sides are found the deposits of clay, sand, pebbles and boulders left by the ancient ice sheet, but the district under consideration is free from glacial deposits of any kind; its topography forms, therefore, a sharp contrast with that of the drift-covered area on every side.

The soils are made up of the residue left from the decay and solution of the surface rocks with a thin covering of loess over a considerable portion of the area. Over most of the region the Galena limestone forms the country rock, and in it most of the ore deposits occur. Overlying the limestone are the soft and easily decomposed Maquoketa shales, which have been largely removed by erosion. Perhaps the most conspicuous features in the topography of the district are the so-called "mounds," isolated, more or less conical and flat-topped hills rising from several hundred feet to 500 feet above the surrounding country. These elevations are commonly capped by Niagara limestone and are the outliers of the formation that have been left by the wearing away of the other portions. They furnish an index of the work accomplished by the denuding agencies that have been acting since the elevation of the land surface above the sea. Several of these marked objects in the landscape are found in Dubuque county, among which Sherrill Mound and Table Mound are well known examples. The former rises 600 and the latter 472 feet above the Mississippi. Sinsinawa Mound in Wisconsin is another conspicuous example.

Before beginning the description of the ore deposits a brief account of the formations occurring in the district may be given.

The strata all have a gentle dip to the southwest so that in ascending the Mississippi the lower members of the series are successively met with. For example, at Dubuque the Trenton limestone is only a few feet above the level of the river but followed northward it is seen gradually to raise 
until a few miles above Guttenberg the underlying Saint Peter sandstone makes its appearance above water level.

Saint Croix or Cambrian Sandstone.-This sandstone is the lowest of the formations which appear in the lead and zinc region. It is found along the streams in the northeastern corner of the state, where it is exposed in the bluffs of the Mississippi, the Oneota and their tributaries. The rock is for the most part a very pure sandstone, made up of rather coarse, rounded and transparant grains of silica. In some portions these are loosely held together by a calcareous or ferruginous cement and the rock is more or less indurated; in other "portions the formation is merely an unconsolidated sand bed. The ledges often present a hard exterior but on removing the outer crust the material crumbles at the slightest touch. Occasional bands of calcareous and argillaceous material appear at certain horizons, especially in the upper 200 feet. At Lansing fully 300 feet of Saint Croix are exposed in the bluffs; and this is capped by 100 feet of the Oneota limestone. This sandstone was formerly quarried at the above mentioned locality, but it furnishes an inferior quality of building stone. Where exposed in the old quarry the rock is a thin-bedded arenaceous limestone with shaly bands in the lower portion.

Oneota Limestone.-The Saint Croix passes above into the Oneota limestone. There are twenty-five to thirty feet of alternating beds of limestone and sandstone at the contact of the two formations, the one rock thus passing gradually into the other without any sharp line of demarcation. The limestone is mostly a coarsely granular magnesian rock containing numerous small cavities. Some portions contain an abundance of siliceous matter in the form of chert. Large beds of this material occur where the limestone has been dissolved leaving behind the hard and insoluble quartz. The rock ranges in color from a very light buff to gray. A good section of the Oneota is exhibited in a quarry one mile north of Lansing where nearly 100 feet of the lower beds are 
exposed. The stone here is fine-grained and of a light cream, almost white, color. The beds are from two to five feet thick, with some well-bedded layers six to eight inches thick.

Lead appears to occur scattered through this rock in considerable quantities, judging from the large amount of "float" that is found throughout Allamakee county. In some instances, as in the case of the Lansing lead mine, the ore occurs in fissures of considerable extent. The above mentioned occurrence of lead in the Oneota is of much interest both on account of the extent of the ore body and also because it is probably the first extensive lead mine ever worked in this formation. It will be fully described in another portion of this report. In thickness the Oneota varies from 200 to 300 feet.

Saint Peter Sandstone.-This rock, like the Saint Croix sandstone is of very pure siliceous sand, composed of rounded and transparent grains of quartz. In some portions the beds are soft and friable, while in others the sand grains are loosely cemented together, and a more or less indurated rock is formed. The formation has a thickness of not over 100 feet. At McGregor where the beds are finely exposed in the bluffs, they furnish an excellent quality of glass sand. As a rule this rock is notably free from any argillaceous or calcareous layers.

These strata have a wide range of color, including white, green, brown, red, buff, yellow, and salmon, all of common occurrence. Where the white and green have been interlaminated by false bedding the contrast between the colors is striking. It is the Saint Peter sandstone that forms the "Pictured Rocks" of the upper Mississippi. An analysis of some of the sand from Clayton showed 98.85 per cent of silica. Very little if any lead is found in this formation.

Trenton Limestone.-The Trenton differs from the three other limestone formations of the region in being a pure lime rock free from magnesia. It is a very compact blue stone characterized by an abundance of organic remains, differing 
thus from the Galena and Oneota, but in the matter of organic remains resembling the Niagara, which is also very fossiliferous. In some portions it is thin and very unevenly bedded, while at other horizons, especially in the lower buff beds near the base of the formation, it is well-bedded, with layers three to four feet thick. Where exposed to the weather the rock changes color as is shown in the quarry blocks which are blue on the interior and gray on the outside next to the joints. This limestone is exposed at various points in Dubuque county, above Eagle Point, along the Little Maquoketa and below Spechts Ferry, for example. In the counties farther to the north it is quite extensively quarried for building purposes. In Wisconsin the Trenton rock carries a large part of the zinc ores, but in Iowa little lead and zinc have been found in it.

Galenc Limestone.-This formation is of special interest and importance as containing the lead and zinc deposits of the state. The rock is a heavily bedded and nearly pure dolomitic limestone, coarsely granular and filled with numerous small cavities. Its color is a buff or light brown, weathering on the surface to a dull gray. Many of the beds have a thickness of seven feet and more, ranging from this to thin evenly bedded layers, near the top. It is in these upper strata that the large quarries in Dubuque, such as those on Dodge street, are situated. The formation contains more or less of argillaceous matter confined mostly to the partings between the beds. Numerous chert nodules also occur at certain horizons. This limestone varies greatly in compactness, being filled with soft patches which are readily affected by atmospheric agencies and soon give rise to the cavities so characteristic of the rock. A weathered surface of Galena limestone always presents a very rough and pitted appearance. Large masses that have fallen from the cliffs look not unlike fragments of scoria from some volcano. Bluffs of this limestone give rise to strange and fantastic forms resembling ancient castles or venerable towers. Wherever cut by streams the Galena lime- 
stone forms escarpments with projecting spurs and isolated turrets. The Galena rock is everywhere cleft by fissures, or crevices, often miles in extent. In these fissures, and in the "openings" formed by their widening out, the lead and zinc have accumulated. The crevices serve as channels for underground drainage and have thus been greatly enlarged until some are the size of a railroad tunnel.

The formation has a thickness of 250 feet when fully developed. Fossils are not very abundant, most of those found being casts. Lingula quadratc is, however, quite common, as is also a species of Receptculites, the $R$. oweni Hall, which is often called the "lead fossil." The upper beds of this limestone are quite extensively quarried about Dubuque and used for curbing, foundations and other rough masonry. It also affords a very good quality of lime.

Maquoketa shales.-The Galena limestone is commonly covered by the soft and easily decomposed Maquoketa shales. In the lead and zinc region these seldom have a thickness of more than thirty feet, though when fully developed they attain a depth of 100 feet and more. In some cases the ore deposits extend upward nearly or quite to the shale. Two small sheets of lead are reported as occurring in the shales themselves, and occasionally good sized pieces of ore are found in the same rock. Most of the shafts in Dubuque county have been sunk through a varying thickness of these shales before reaching the ore deposits.

Niagara Limestone.-Overlying the Maquoketa beds is the Niagara limestone, which forms a line of bluffs rising abruptly six or seven miles west of Dubuque and gradually approaching the Mississippi south of the city.

\section{MODE OF OCCURRENCE OF LEAD AND ZINC.}

It may be stated as a general law that the ore deposits of the world, including those of lead and zine, are located within areas of disturbance in the earth's crust. The strata have been more or less tilted from their original horizontal position; 
they have been fractured and faulted, and in numerous instances masses of igneous rock have been intruded into them.

The ore deposits of the Upper Mississippi form a notable exception to the above rule. They occur in practically undisturbed strata, which show no evidence of having been subjected to powerful dynamic forces nor of having been affected by igneous intrusions. It is true, as will be noted later, that slight anticlinal folds exist in the region, but these are of minor importance and have not given rise to profound fissures or faults.

While some beds of lead and zine occur in massive or crystalline rocks, the great majority of the world's deposits, including those which are most productive, are found in limestone or are closely associated with that rock. "This fact is one of much significance since it does not hold true for deposits of the other metalliferous ores. As illustrations of lead deposits in limestone may be mentioned those of Colorado, Montana, Idaho and Nevada; those of the Mississippi valley, and in Europe the large mines of Upper Silesia, Laurium, Cartagena, Santander, Bleiberg, North of England, Sardinia and numerous others.

In their geological distribution these ores are not confined to any one horizon or group of strata, but are scattered through rocks of all periods from Archæan to Tertiary. The rocks, however, which contain the largest and most important deposits are those of the Silurian, Lower Carboniferous and Triassic. The Iowa mines are confined to the Lower Silurian.

A brief comparison of the Upper Mississippi mines with those of Missouri will be in place here. The Missouri mines are grouped about certain centers and are included in three districts, the southwestern, southeastern and central. In the southwest almost all the deposits are in the Lower Carboniferous limestones and cherts. In the southeast and central districts they are in the Lower Silurian limestones. 
The massive form of ore deposits prevails in the southwest; the ore bodies are extensive accumulations of breccia, the fragments being principally chert derived from the country rocks. In the southeast the Galena is disseminated through the country rock, large masses of magnesian limestone being impregnated with the mineral.

The Missouri deposits are thus of three kinds:

(1) Filling crevices, chambers or caverns, such as occur in all three districts.

(2) Brecciated deposits of the southwestern and central districts.

(3) Deposits impregnating the country rock of the southeastern district.

The Missouri deposits resemble those of Iowa in the absence throughout most of the region of great fissures and faults, and also in being confined to beds near the surface.

\section{THE LEAD AND ZINC ORES AND ASSOCIATED MINERALS.}

The only ore of lead that is found to any extent in the Iowa mines is the sulphide, Galena ( $\mathrm{Pb} \mathrm{S}$ ). The carbonate, Cerussite $\left(\mathrm{Pb} \mathrm{CO}_{3}\right)$, is of rare occurrence, and is derived by alteration from the more common sulphide.

Galena.-This mineral occurs as a rule in well defined cubes, which are joined together in masses of greater or less size, forming groups or aggregates of crystals. The corners of the cube are sometimes replaced by the faces of the octahedron, and this form may predominate until, in rare cases, the cubic faces have disappeared altogether. All the specimens observed from the mines directly about Dubuque were clusters of cubes unmodified, but the Galena from a section lying south of the city, as well as that from the Guttenberg mines, is crystallized in forms showing the combination of the cube and octahedron. From the last mentioned locality a few unmodified octahedrons were obtained.

The crystals seldom present bright metallic surfaces, the faces being dull and more or less corroded or coated over 
with some foreign substance. The miners have different names for the various kinds of lead ore. Thus the term "cog mineral" is applied to groups of good sized cubic crystals. When these are small the ore is called "dice mineral." When the sulphide occurs filling a narrow fissure, it is rarely well crystallized, and is then known as "sheet mineral," and when occurring in irregular masses it is called "chunk mineral."

The lead from the Iowa mines, like that from the other regions of the Mississippi valley, contains only a trace of silver, and is known as soft lead in contrast with the argentiferous ore of the western mines. More or less of silver is almost invariably present in lead ore, especially when the latter is found occurring in the neighborhood of metamorphic or igneous rocks. But the deposits found in undisturbed sedimentary strata commonly contain no silver except in very small amounts.

It requires at least six ounces of silver to the ton to pay the cost of extracting, and the Iowa ores carry a percentage less than this. The Galena is very free from impurities of any kind and furnishes a product of excellent quality.

Cerussite.-This mineral occurs as a coating upon the sulphide and also at the Lansing mine in crystals lining small cavities in the Galena. The ore from this mine is also frequently covered by a thin layer made up of numerous, small, twin crystals of Cerussite. Wherever the Galena has been long exposed to the weather, as in the case of the float lead found in the soil, the carbonate supplies it with a white coating. In the formation of the Cerussite, which is evidently a secondary mineral formed by the alteration of Galena, the sulphide is first converted into the sulphate $\left(\mathrm{Pb} \mathrm{SO}_{4}\right)$ and the latter, through the agency of water holding bicarbonate of lime in solution, is transformed into the lead carbonate.

Smithsonite.-The zinc ores found in Iowa are the carbonate, Smithsonite $\left(\mathrm{Zn} \mathrm{CO}_{3}\right)$ and the sulphide, Sphalerite or Blende ( Zn S). 
The carbonate, or "dry bone" as it is commonly called, is by far the most common in the Dubuque mines. It occurs in a variety of forms which may be described respectively as cellular masses, botryoidal coatings, earthy masses and small bodies impregnating the rock. It often bears a close resemblance to the calcareous tufa found about so many springs in limestone regions. Sometimes it supplies a coating for galena crystals, or it entirely replaces them and forms pseudomorphs. Several interesting specimens were seen in which fossils had been entirely replaced by the carbonate. One of these was a slab of Smithsonite on which were several large gastropods, their substance wholly gone and the place filled by zinc ore, the outline being perfectly preserved. The carbonate contains, on an average, from 30 to 40 per cent of zine, though some specimens run as high as 49 per cent.

Sphalerite.-The sulphide, the "black jack" of the miners, is much less abundant in the Iowa mines than the Smithsonite. This is doubtless due to the transformation that has taken place, by which the former was changed over into the carbonate as will be explained later. The blend commonly occurs in compact layers or masses, and does not exhibit any crystal form. But crystals are by no means rare, being found in cavities in the limestones or in geodes. The sulphide contains considerable iron which imparts a very dark, almost black, color and renders the mineral opaque.

The zinc silicate, or Calamine, was not observed in any of the mines, though it probably exists in small quantities along with the Smithsonite.

The change of the sulphide to the carbonate seems to have been very extensive, and the latter is probably all of secondary origin and derived from the blende. Several facts indicate that the latter has been the source of the carbonate.

(1) Specimens are very common in which the outside is dry bone, while the unaltered interior is composed of the sulphide. (2) In the lower levels and where water abounds the ore is the Sphalerite. This is the universal rule and would 
seem to be owing to the fact that the lower deposits are not subjected to the atmospheric agencies at work nearer the surface. The chemical changes that have taken place in the zinc blende are probably as follows: The sulphide ( $\mathrm{Zn} \mathrm{S)} \mathrm{in}$ the first place became by oxidation the sulphate ( $\mathrm{Zn} \mathrm{SO}_{4}$ ) which is a very soluble compound; then through the agency of the alkaline and earthy carbonates in solution in the circulating waters, the zinc sulphate would be changed into the carbonate and redeposited in the crevices. Where the blende is under water it is little affected by oxidation and hence remains unaltered.

\section{ASSOCIATED MINERALS.}

A variety of different minerals occur in the same crevices along with the lead and zinc, and these deserve more than a passing notice since they serve to throw light upon the origin of the two associated metals.

Pyrite and Marcasite.-These are very common in the workings and are the "sulphur" of the miners. They have the same composition with a ratio of 46.7 of iron and 53.3 of sulphur, but crystallize in different systems, Pyrite being isometric, and Marcasite orthorhombic. The latter is commonly whiter than Pyrite. They do not occur in well defined crystals so much as in crystalline aggregates of irregular form.

At the mine of the Dubuque Lead Mining company, however, the Pyrite is found well crystallized. The limestone has here been much affected by dissolving agencies and is so filled with cavities that the rock has somewhat the appearance of a breccia cemented together by iron pyrites. Instead of the more common cube the mineral here occurs in perfect octahedrons sometimes modified by the faces of the cube. Penetration twins are also of "frequent occurrence. The crystals vary in size from one-fourth to three-fourths of an inch. When exposed to the air these sulphides readily oxidize and change over into Limonite. This alteration is finely illustrated in a specimen from the Lansing lead mine. The interior is made up of Marcasite while on the outside this has 
undergone a chemical change and a coating of Limonite onefourth of an inch thick has been been formed. The same specimen is covered on one side by Galena and on the surface thus protected the Marcasite has suffered but slight alteration, showing that the changes took place after the deposition of the Galena on the iron sulphide. Otherwise there would seem to be no reason why the Limonite should not be of the same thickness on all sides.

Limonite. (Ocher. Rust.)-This is a hydrated oxide of iron and is found in large quantities in the ore-bearing crevices where it was formed by the oxidation of the Pyrite and Marcasite. This alteration process has gone on so extensively that a large part of the original minerals has been changed into the iron oxide. It is usually impure and earthy, imparting to the clay and other crevice material a brown color.

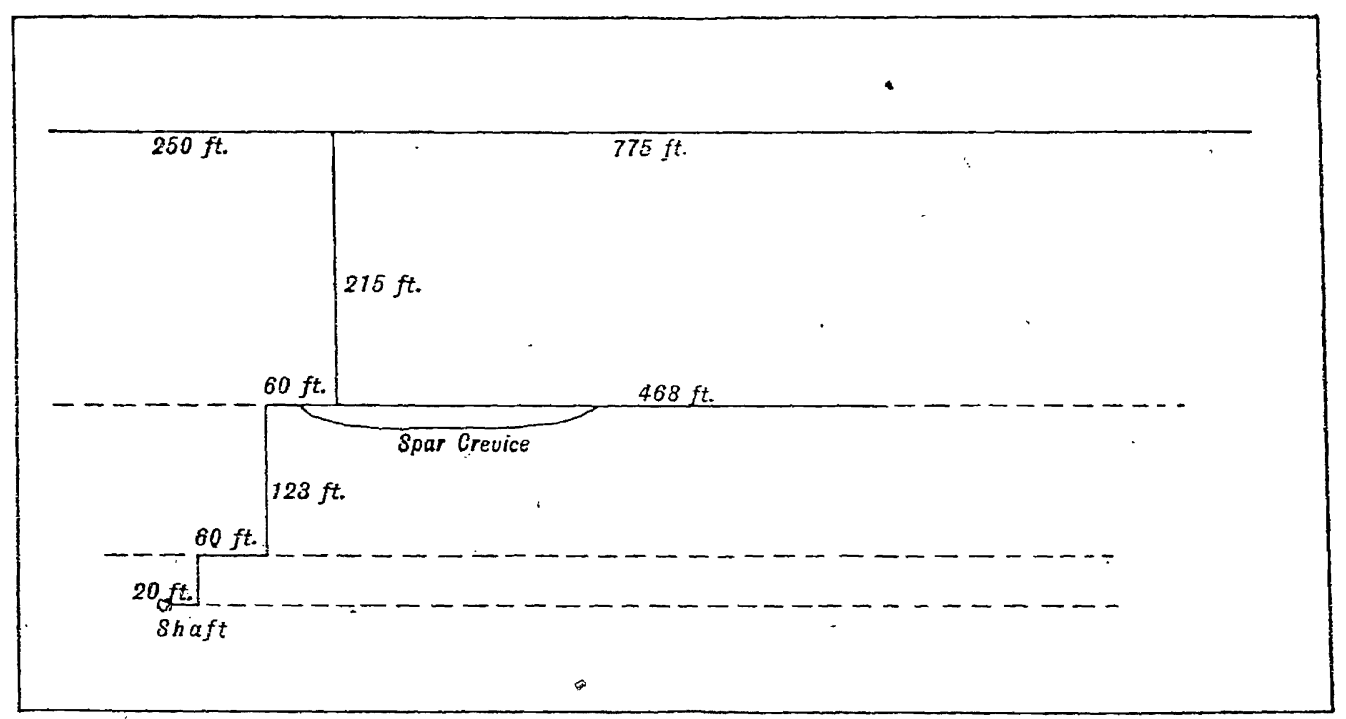

FIG. 1. Crevices followed in prospecting for lead south of Dubuque. These crevices contain satin spar and stalactites.

Calcite and Aragonite.-These are the most common of the associated minerals, occurring abundantly throughout the region. The following varieties were observed:

1. Well crystallized calcite; the "tiff" of the miners.

2. Fibrous variety or satin spar.

3. Lamellar, pearly white variety or argentine. 4 G Rep 
The two latter are closely associated and are found together in the same stalactites.

The crystallized calcite forms fine crystals and groups of crystals often of much beauty. A very common occurrence is the combination of the scalenohdron ( $\mathrm{R}$ 3) with the rhombehedron $(R)$ and the prism of the first order $\left({ }_{\infty} \mathrm{P}\right)$. But more complex combinations are found. Thus one specimen showed the prism of the first order and three scalenodrons, two positive ( $R 3$ and $\frac{1}{4}, R$ ) and one negative, the latter beveling the acute angles of $\mathrm{R} 3$.

Satin spar and argentine are associated in some crevices about five miles south of Dubuque.(Tp. 88 N., R. III E., Secs. 16 and 17).

Some of these "spar caves" have been prođuctive crevices

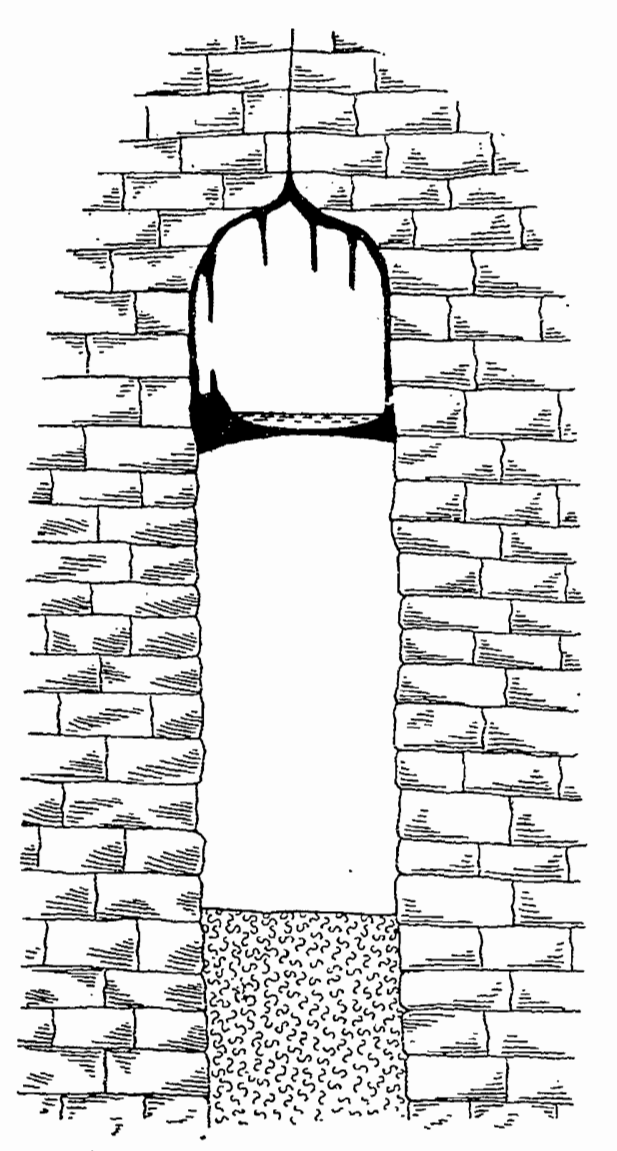

FIe. 2. Section through Kemling's spar care showing floor suspended in top of crevice, stalactites and miniature lake.

calcium carbonate 6-10 inches from which large quantities of ore have been taken, while others are barren and filled to a greater or less extent with clay. The Galena limestone in this locality is cleft by a complex system of extensive fissures which form a labyrinth of underground passages, and in certain portions contain large deposits of calc spar lining the top, sides and bottom. The deposition of lime carbonate does not go on extensively where there is more than forty feet of limestone above the cap rock. One remarkable feature of these "caves" deserves more than a passing notice. The floor, which is formed of a layer of thick, is suspended in the top 
of the crevice. This is well shown in the accompanying figure (Fig. 2). The floor was evidently formed when the clay was at that height in the fissure and was deposited on top of this impervious material. Later the clay has settled, leaving the crevice open beneath the lime deposit; sometimes this settling amounts to as much as thirty or forty feet. The floor of the cave thus forms a horizontal partition across the top of the crevice. It may be connected with the roof by several columns formed by the growing together of stalactites and sta-

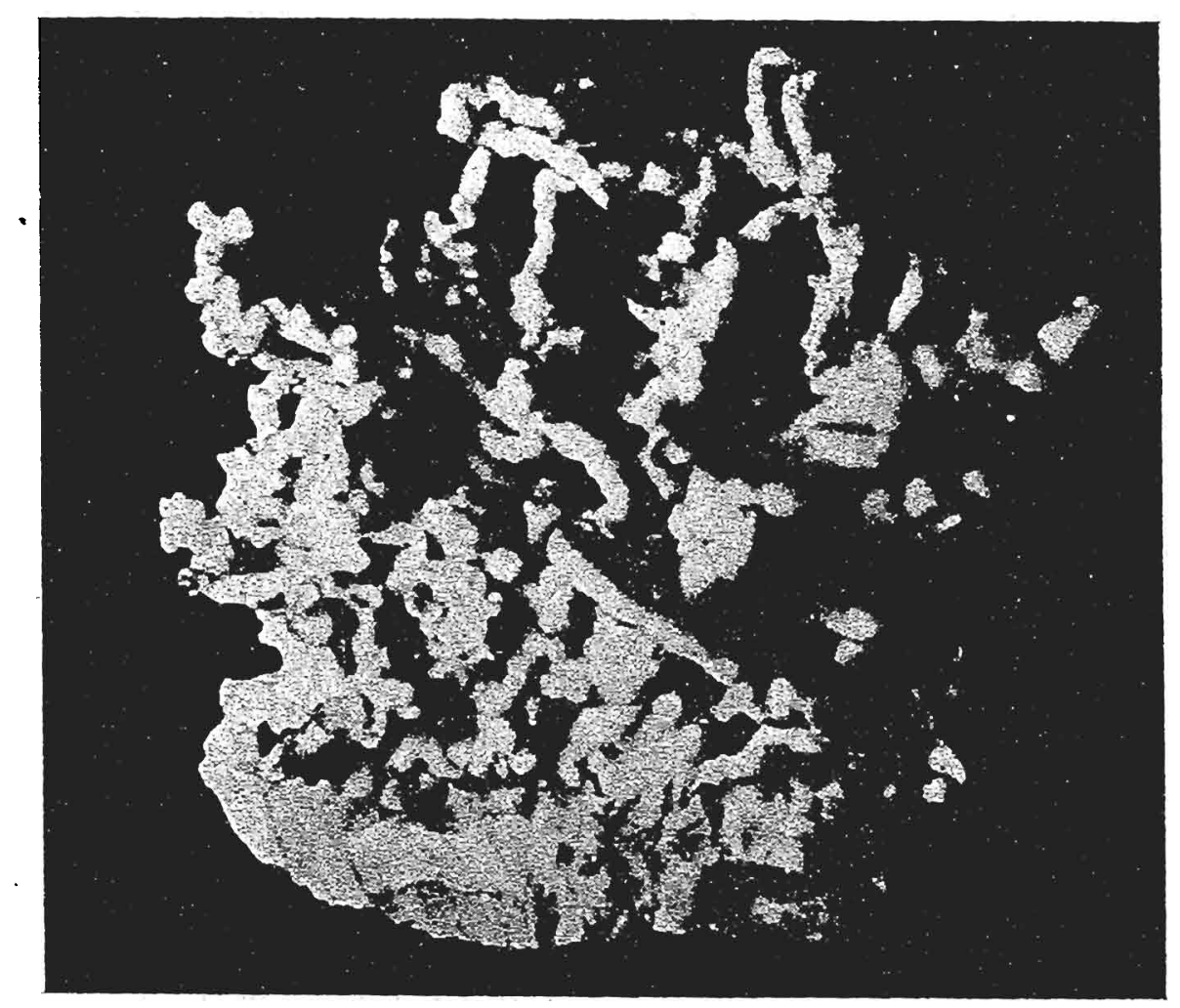

FrG. 3. Satin spar showing twisted stem-like forms. Linden's cave, south of Dubuque.

lagmites. On this floor is sometimes found a clear pool of water.

The Satin spar has a fibrous structure, silky luster and is colorless or white. It is made up of delicate acicular crystals of Aragonite.

The Argentine (Schieferspath) has a pearly luster and is composed of more or less undulating lamellae of pure white color. 
The specimens found here agree well with the descriptions given by Dana and Tschermak. Several different forms of stalactites occur: (1) Those specimens which are pearly. white on surface of fracture, with a silky luster due to the radiating fibers that form a velvety surface of great beauty. This variety occurs in bunches or clusters of twisted and gnarled stem-like forms. (2) Stalactites proper; formed of radiating fibers. In cross section these have a vitreous

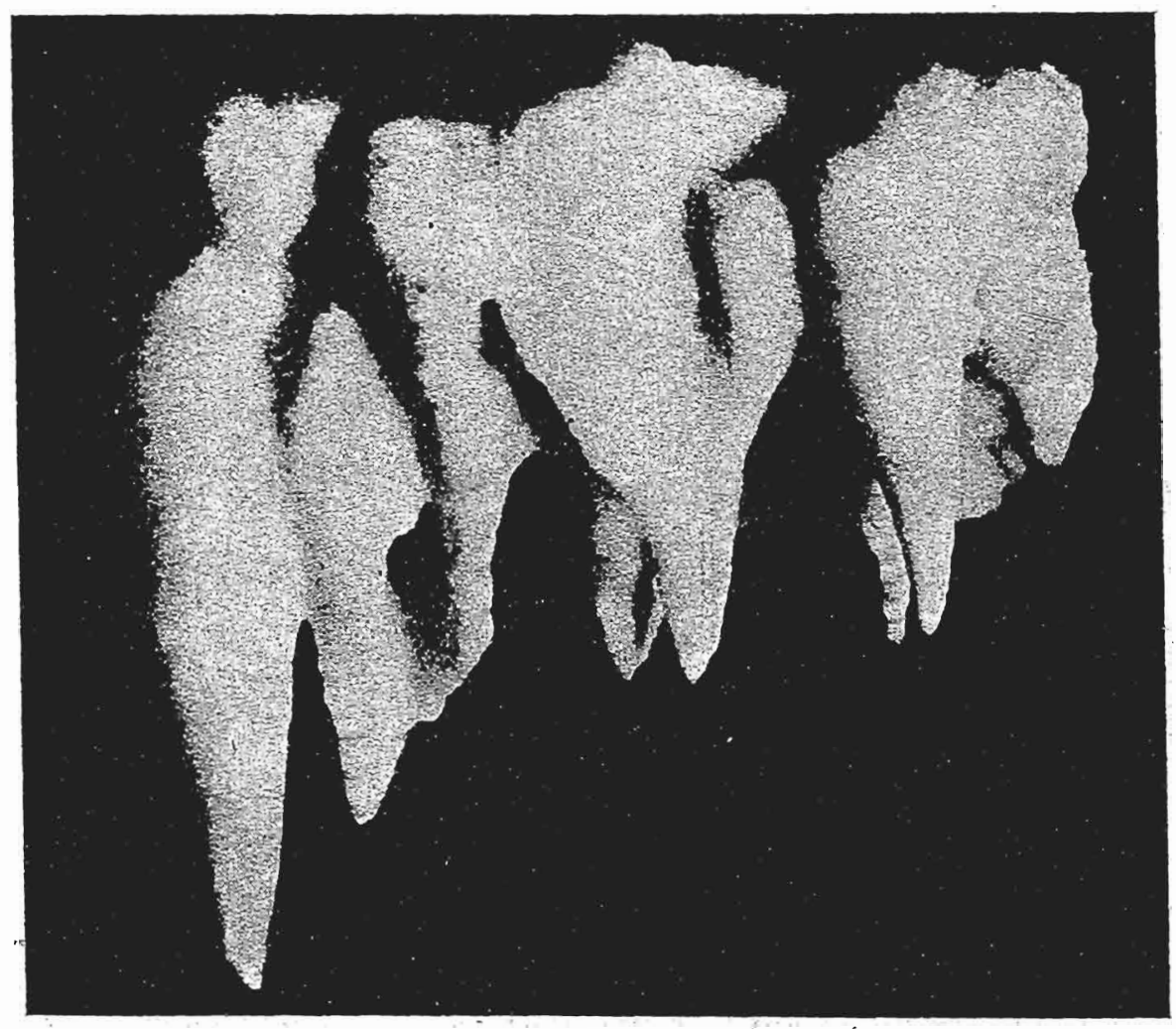

FIG. 4. Group of Stalactites from Kemling'scave; south of Dubuquàe.

luster, and on the surface are (a) either covered with a fine white powder, and show no luster or (b) the outer surface is formed of little rhombohedrons and has a silky luster. They are white or colorless; opaque or translucent.

Other stalactites have a concentric banded structure and possess several points of unusual interest. Beginning at the center they show (1) a crystalline or granular core, often displaying bright rhombohedral faces; (2) a thin band of clay, 
apparently wanting in some cases; (3) pearly white lamellar Calcite (Argentine); (4) a band of clay; (5) a fibrous Aragonite; (6) an outer surface composed of little rhombodedrons.

Several features in the structure of these stalactites deserve special notice. There is every indication that the crystalline core was once fibrous, but this structure has mostly disappeared, especially in the larger specimens, and is replaced by the rhombohedral cleavage. In the smaller forms the transition from the radiating fibrous variety to the crystalline aggregate of rhombohedrons can be traced. The long acicular crystals become less and less distinct, though traces remain visible after the rhombohedral form makes its appearance. Recrystallization has taken place and the molecules have rearranged themselves to conform to the interior structure of the rhombohedron; or in other words, they are identical with the latter crystal form in all but external outline and this has been prevented from developing, showing itself only on cleavage faces. Another strong indication that this granular core was once fibrous is found in the fact that this latter structure is the common one in all these caves. The small forms all show the radiating fibers but as they increase in size alteration has taken place.

Another point of interest relates to the band of pearly lamellar Calcite occurring between the granular, crystalline core and the fibrous external layer. These white lamellæ form concentric rings in marked contrast to the radiating fibers associated with them. Occurring on both sides of the Argentine in most cases if not in all, there is a thin band of clay. It is this that doubtless marks the suspension of deposition for a time, and when redeposition commenced the conditions were so changed that a different variety was formed.

The rhombohedrons forming the surface while the interior is fibrous, also deserve notice. They occur on the larger stalactites but not on the delicate branch-like forms. The exterior of the latter owes its silky luster to the innumerable. 
fibers of which it is composed. They frequently form delicate cotton-like masses covering the outside of the satin spar.

On the majority of stalactites, however, the crystal aggregate of rhombohedrons occurs. They may have been deposited after the radiated interior was formed, but they seem to be due rather to the alteration or recrystallization of the fibrous mass, as in the case of the granular core. The conditions under which the fibers were formed have changed, and there has been a corresponding change in the crystalline condition of the calcium carbonate.

The satin spar occurring in the large branch-like clusters is notable on account of its great beauty and rarity. As it

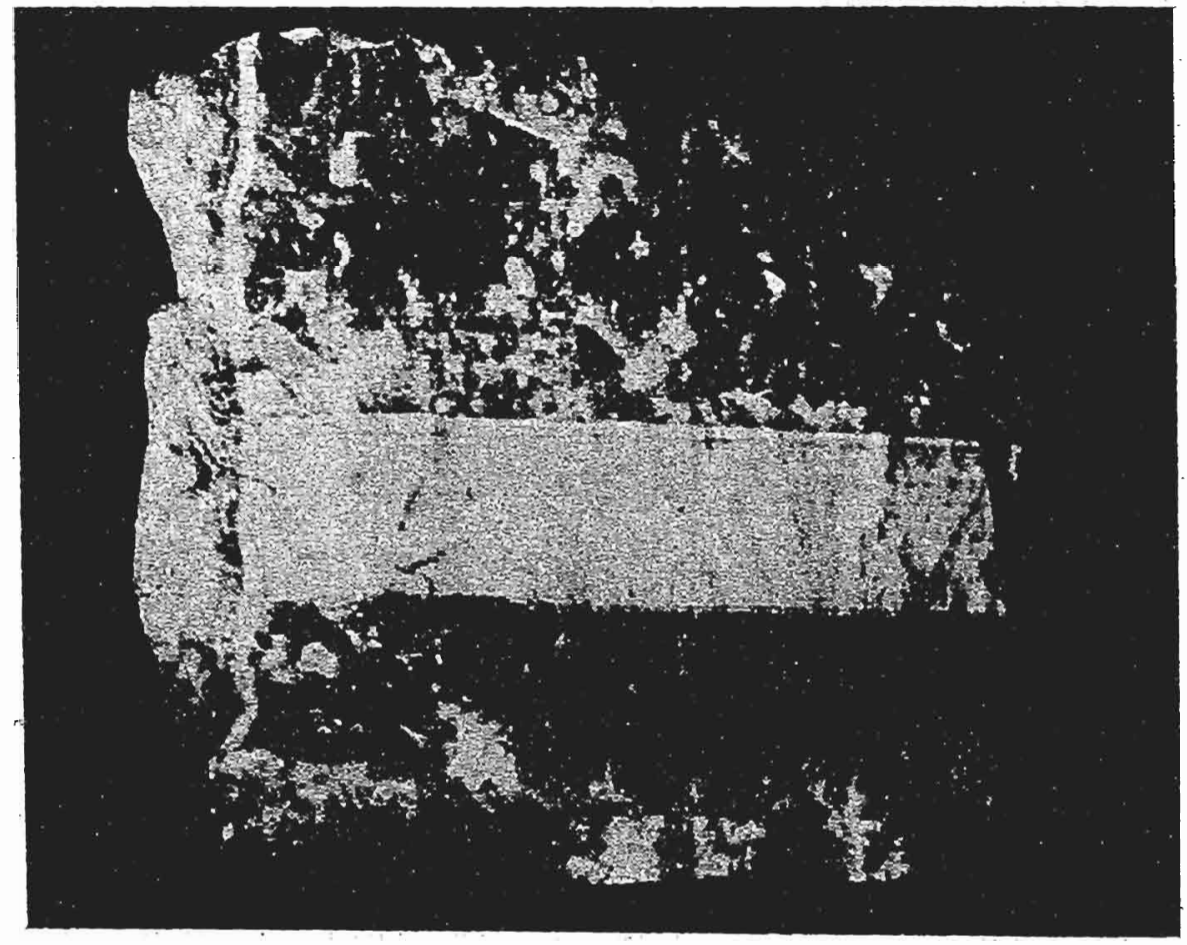

FIG. 5. Specimen showing band of pearly Argentine in transparent' calcite from floor of Kemling's cave, soith of Dubuque.

hangs suspended from the roofs of the caverns it resembles at a distance branching coral, but near at hand the twisted and gnarled stems with their beautiful silky luster bear no likeness to the polyp structures. 
There are several ways of accounting for these irregular forms. They are perhaps due in some cases to the air currents which move through these underground passages. The wind, coming now from one direction, now from another, causes the drops holding the lime in solution to be blown to one side and another of the slowly growing stem, the drops being held by the surface tension of the solution. The water does not trickle down undisturbed as when forming the long straight stalactites, depositing the carbonate evenly on the ends and sides, but is deposited for a time on one side of the branch and then on another.

In a recent paper* on the formation of stalactites Merrill describes some irregular forms from Wyandotte cave, Indiana, and ascribes their peculiar shapes to capillarity. He says: "An examination of the medusa-like forms of Wyandotte reveals the fact that they occur not as dependents from the naked limestone of the roof, but are offshoots from a stalactitic crust which forms first and which varies from a mere film to several inches in thickness. They occur sometimes singly but more commonly in groups or clusters of several, ranging in size from three to ten $\mathrm{mm}$. in diameter. Closer inspection reveals the fact that while in most cases tubular, the tube itself is of almost microscopic proportions, being as a rule less than half a millimeter in diameter. So small is it in fact, that capillarity, not gravity, is the controlling principle in giving direction to the lime-carrying solution. A small spicule of calcite crystallizing on the extremity is as likely to point any other direction as downward; the direction of the next drop is controlled in part by the first, when the same process is repeated. On the assumption that the stalactite increases in length by constant addition to the tube on all sides, it is easy to imagine that the deposit takes place for a time more rapidly on one side than another, perhaps partially closing the orifice or giving it a different direction. The essential fact is, however, that it is to capillarity and not to gravity, that is due the peculiar vermicular forms."

*Proc. U. S. Nat. Mus., Vol. XVII., pp. $7 \%-81$, 
It is not unlikely that some at least of the Dubuque stalactites, and possibly all, have originated in the manner just described.

Gypsum.-This mineral is not of common occurrence in the region under view. It is, however, occasionally found in the crevices along with the ores. There is a very unusual occurrence of crystallized Gypsum, or Selenite, in the "spar cares." The specimens are found on the top of the clay forming the floor. The Selenite occurs in very long acicular crystals. These needle-like forms are composed of two individuals, whose twinning plane is the orthopinacoid $(\propto \mathrm{P} \propto)$, and are greatly elongated in the direction of the vertical axis. The faces which appear are those of the clinopinacoid $(\infty \mathrm{P} \propto)$ and unit prism $(\propto \mathrm{P})$.

Two cleavages are well shown: (1) The most perfect is parallel to the clinopinacoid; (2) there is a second good cleavage parallel to the negative pyramid $(-\mathrm{m} \mathrm{P})$. The extent to which these twin crystals have been elongated is remarkable. One specimen had a length of $6 \frac{1}{2}$ inches, with a width of less than $\frac{1}{4}$ of one inch. Another was $5 \frac{1}{4}$ inches long and extremely slender, being less than $\frac{1}{16}$ of an inch wide and perfectly transparent.

Dolomite.-Crystallized dolomite is not common, and when found usually lines the sides of small cavities in the limestene. Since the latter is highly magnesian, it might be expected that dolomite would more frequently occur, but its rarity is doubtless due to the greater solubility of the magnesian carbonate. On this account it would remain in solution while the lime carbonate was deposited.

\section{MODE OF OCCURRENCE 'OF THE IOWA ORES.}

The lead and zinc deposits of the state are found in crevices in the Galena limestone. The strata of the region are cut by fissures of greater or less extent, and in the expansion or "openings" of these the ores occur. There is a very noticeable uniformity in the general direction of the crevices, 


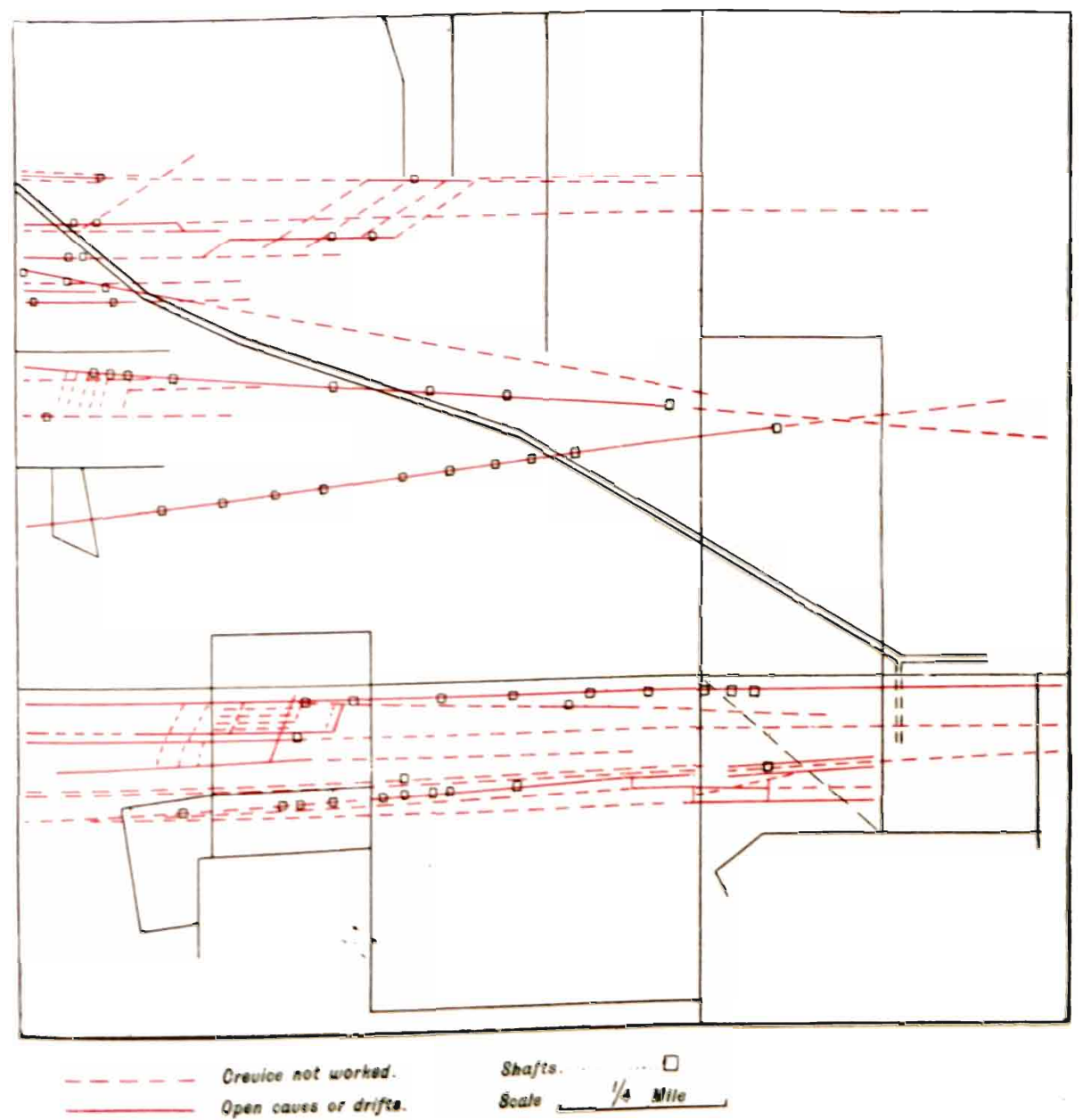

TyPICAL CREVICE AREA NEAR DUBUQue. 
a greàt majority, and all of those which carry the large ore bodies, have an approximate east and west course. A less important set bear north and south; these are narrow without any true opening, and in them the ore occurs without exception in sheets. Cutting these two sets of fissures there are others known as "quarterings" that cross the former at varying angles. These seldom form open crevices and rarely carry ore; but where they cut the main crevice large ore bodies are apt to occur, and these secondary clefts are called by the miners "feeders."

The system of east and west fissures deserves special notice. They have yielded most of the lead and zinc and are by far the most extensive. While their general direction is nearly east and west they vary more or less from such a course. This variation will not, however, exceed ten degrees, and most of the crevices of the Dubuque district are found to bear a few degrees, from one to ten, south of west. Excepting where several are associated together forming a range, the crevices are not parallel and no two have exactly the same direction. Thus it happens that they approach or recede from one another and in some cases even intersect.

The great extent of many of these crevices is another remarkable feature. They extend for miles across the country, and, excepting slight local deviations, their course is nearly a straight line. Thus in some instances, when the true direction was found and a shaft sunk on this line, it struck the opening, or perhaps missed it by only a few inches. The Timber range, a few miles north of Dubuque in Peru and Jefferson townships, affords a good example of the length of some of these fissures. The range is composed of three main crevices which are parallel, with several minor ones, and has a width of 100 feet. It has been worked for a distance of five miles or more, in some portions yielding lead and in others zinc.

The crevices composing a range are quite closely related. They are parallel, only a few feet apart, and are connected by 
cross fissures. The ore may give out in one, but will be found again in the next neighbor to the north or south. It is

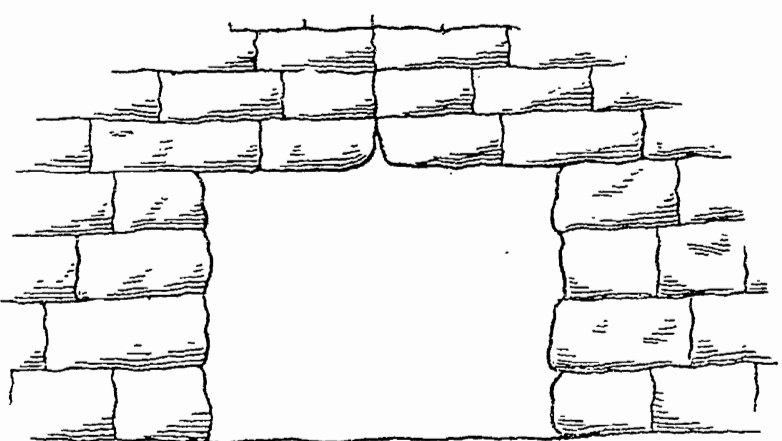

FIG. 6. Orevice opening in Spring Street mine of Dubuque Zinc and Lead Mining Co.

thus not uncommon to have the ore pass from one crevice to another in the same range.

The characteristic features of the crevices are the "openings." These are formed by a widening process due to the decomposition and solution of the limestone in these particular layers. They serve as channels for underground drainage and have thus in many instances been greatly enlarged. These cave-like

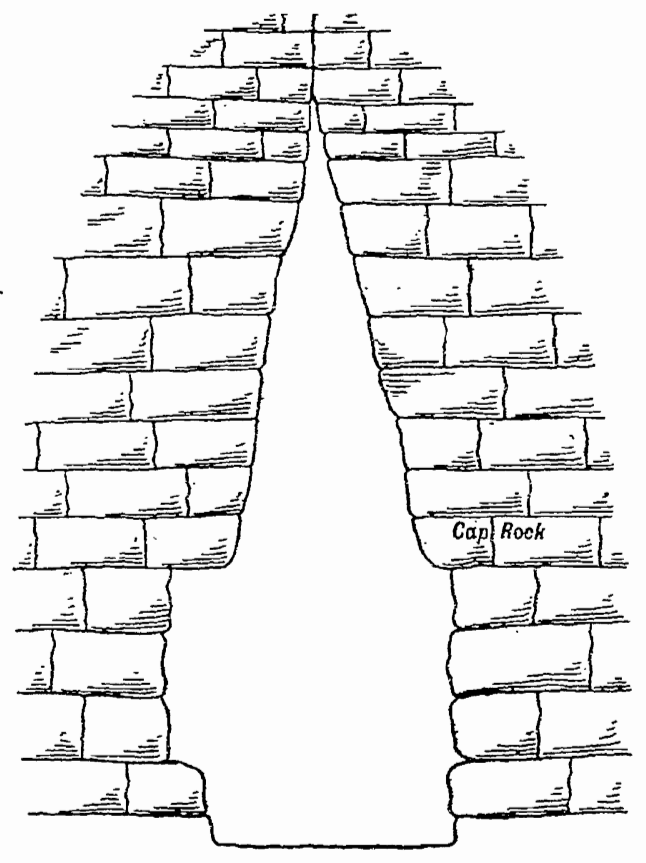

Fra. \%. Section showing open crevice extending up through cap rock, mine of Dubuque Zinc and Lead Co. expansions usually include several strata, the rough edges of which form an irregular wall on either side. At the surface the fissure commonly appears as a mere seam or crack in the rock, which, followed down, probably contains little or no mineral until it suddenly widens out into the space where the ore, if anywhere, will be found. The openings vary. greatiy in dimension; in height they are all the way from a few feet to forty, and in width from several inches up to twenty feet, and in rare cases even forty feet. They are usually limited above by the "cap rock," a hard and persistent layer of limestone four feet in thickness. This is almost invariably cut through by a seam which may be so small as scarcely to be distinguished, or by 
an open fissure of varying width that often carries ore. A section of the Galena limestone above the "cap rock" is given below. It is seen in no one locality, but is made up from records of shafts and from quarries.

1. Maquoketa shailes

FEET. INCHES.

2. Bright red to yellow, cavernous limestone._ 4

3. Compact blue limestone, difficult to penetrate (the "blue rock" of miners) ........ 20

4. Regularly bedded limestone, layers $4-12$ inches thick ("quarry rock") ............ 20

5. Heavily bedded limestone.................. 10

The "cap rock" composes the lower portion of No. 5 , is 3 to 4 feet thick and is more compact and hard than the beds below. It is quite easily recognized in sinking a shaft, and among the quarrymen is known as the "four-foot" layer. The lower portion of the above section is well shown in several extensive quarries on Dodge street, below Grandview avenue, Dubuque. These have reached a depth of twenty to forty feet below the surface. Nos. 4 and 5 are well exposed. The layers of the upper portion of No. 4 are uniform in thickness and separated by clayey matter:

The "four-foot" layer is well shown in the quarry north of the road. It is here broken through by several crevices and in one place a large east and west open fissure extends up into the "cap."

A crevice does not widen out into a single opening only, but into several, one below another. The upper is commonly called the "first" opening, the next

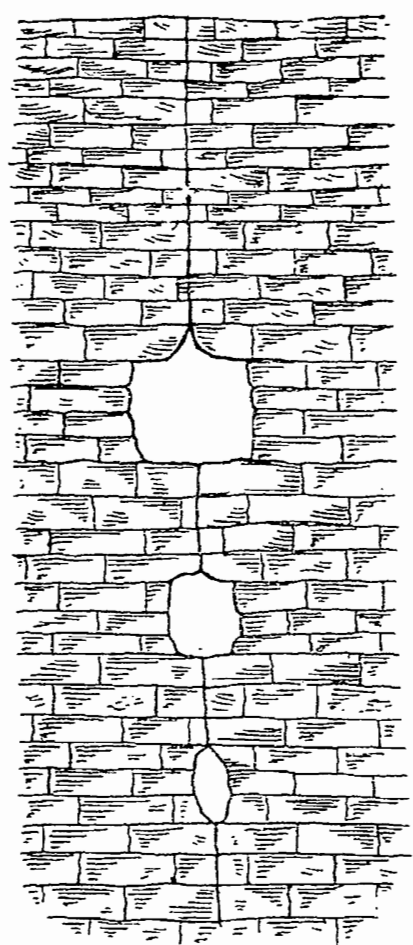

Frg. 8. Crevice with three openings. underneath the "second," while still farther down are a third and fourth. (See figure 8.)

About Dubuque only the first openings have been extensively worked, though considerable ore has been removed from the 
second. But water hinders progress at the lower levels, and it is only by resorting to costly pumping machinery that these can be reached. The upper opening is usually the main one and also the most productive, while the lower ones are smaller and contain less clay; the ore in these being therefore clean and bright. The first opening is found to occur forty-five to fifty feet below the Maquoketa shale, that is to say the opening proper is at that depth below the shale, and yet it frequently extends upward through the cap rock as an open crevice scarcely to be distinguished from the opening itself, though the miners always make the distinction. As a rule it is not so wide as the portion below the cap rock, just beneath which the marked enlargement occurs. (Figure 7.) This open crevice often extends to within a few feet of the shale or even quite up to it.

A peculiar feature of many openings is found in the chimneys that continue above the general level of the roof, as large cone-shaped or irregular cavities commonly also carrying ore. (See figure 9.) On the other hand the opening may

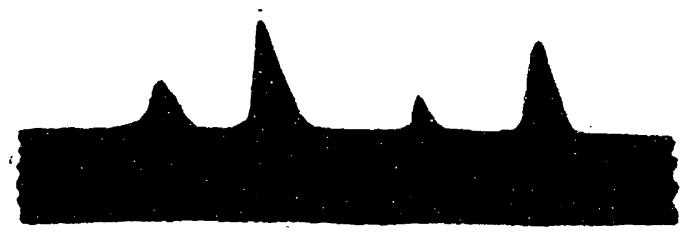

FrG. 9. Crevice opening with chimneys. widen out into spacious rooms or caves. Again, the crevice may be divided or almost blocked up by alarge mass of limestone known as a "key rock." It is doubtless on account of its greater compactness that this obstruction has been able to resist the destructive forces which have removed the surrounding rock. The opening is not necessarily an empty cavity, but may be partially or entirely filled with ore or crevice material, such as clay and rock fragments. On the other hand the openings are often empty and can be traversed for hundreds and even thousands of feet.

The simplest mode of occurrence for lead and zinc is in that of the verticle sheet. (See figure 10.) In this case the ore is found filling a narrow fissure, the walls of which are parallel, and the entire space between them is filled with 
galena or blende; or the rock may have decomposed more or less, and some clay will then be present enclosing the sheet. The thickness of the latter is variable but will seldom exceed three inches, diminishing to a quarter of an inch and less. The longitudinal extent is usually not great.

A fine example of such a sheet is furnished by the Lansing lead mine in Allamakee county. This, like all such, lies in a

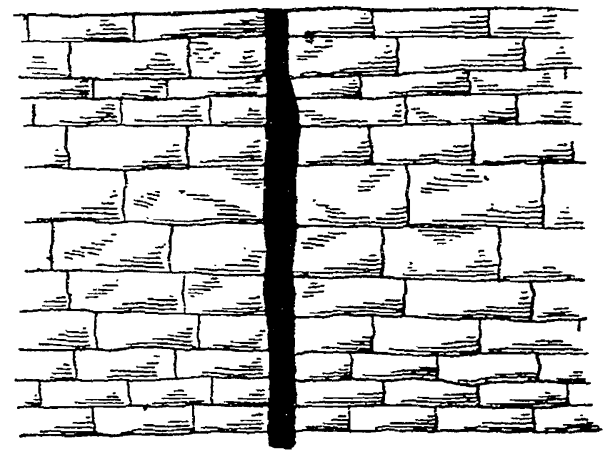

FIG. 10. Occurrence of lead as vertical sheet. north and south fissure, has a thickness of three inches, and a vertical extent of at least thirty feet. Though followed for 1,000 feet, its northern and southern limits have not yet been reached. This mine will be more fully described later.

The above occurrence, however, is exceptional in the Iowa mines. Most of the ore occurs in the openings above described, where it is either pure or mixed with more or less of clay and fragments of rock. It is commonly found attached to the top and sides of the cavities, or has fallen to the floor where it lies partially buried in clay. The lead, especially, bears evidence of having been formed in the "cap." It is frequently seen suspended in large masses from the roof and extending up into the crevice in the "cap rock." After it has faillen, a second sheet may form in its place, and thus several separate masses may be formed successively. Lead is also found filling the chimneys and continuing upward above the opening. The zinc ore, besides lining the crevice, is also found in large, loose masses, nearly filling the opening and coating the loose rock fragments. Oftentimes it is quite pure, with only a slight admixture of clay or limestone. Sometimes it fills great cavities, and in one of these it was so loosely deposited that a blow of the pick caused tons to come tumbling down. 
A very noticeable feature of the Iowa deposits is seen in the way the lead and zinc occur concentrated at certain points forming "ore bodies." The crevices are not productive throughout their entire length, but only here and there, where, for some reason, the conditions have been exceptionally favorable for the concentration of the minerals. It may be that a quartering crevice or a north and south fissure intersects the main one just here, and has brought in the waters from which the ore was deposited. At any rate, these ore bodies frequently occur where several crevices cross. In a great many cases also they appear to accumulate and "make back" as the miners say, from some obstruction in the crevice, as a "key rock." These concentrated masses of mineral do not usually extend more than 300 or 400 feet, though they may reach 800 or 1,000 feet. The opening, on the other hand, may be several miles in length. The ore bodies are thus commonly quite limited. They do not usually give out suddenly, but the valuable contents diminish in quantity and finally disappear.

The lead and zine deposits of Iowa are confined mostly to the upper part of the Galena limestone. This is true for all the mines of Dubuque county. Farther north at Guttenberg, where formerly considerable lead was found, the mines are in the lower portion of this formation, and at Lansing some ore is even found in the Oneota limestone; but with few exceptions the deposits are near the top of the Galena. The Iowa mines appear to form an exception to the rule that holds good for the rest of the region. Chamberlain* makes the following statement concerning the occurrence of the metals in the field as a whole. "It is a law to which no noteworthy exceptions have yet been authentically reported, that lead predominates in the upper beds, but relatively decreases in the lower, while the zinc ores are very scant in the upper horizons but relatively increase and often predominate below." If reference is made only to the zinc blende, then the above

*Geology of Wisconsin, Vol. IV, 1873, p. 488. 1879. 
statement would be true for Iowa as well, for the sulphide is always found at the lower horizons and usually below the Galena. But if it is made to include the zinc carbonate or dry bone, the Iowa deposits are an exception.

In the Dubuque region the zinc commonly occurs on the same level as lead, and in some cases above it, as will be shown later. Most of the great ore bodies have been in the upper fifty or sixty feet of the Galena limestone, and it is doubtless true that the bulk of both minerals so far marketed from these mines has been taken from the upper one-fourth of that formation. Very little ore has been removed from a greater depth than 100 feet below the Maquoketa shale. In Wisconsin the zinc is confined mostly to the underlying Trenton rock, but only in rare instances have the diggings reached that depth upon the west bank of the Mississippi.

Both lead and zinc frequently occur in the same opening, though they are not usually intermingled. The lead gives out in the crevice and a short distance beyond the zinc appears. Thus many crevices have been worked in one section for the former and in another for the latter. The carbonate is found in immense quantities above the openings carrying the lead. The two ores rarely occur mixed together in the Iowa mines, and even in such cases it is only in small amounts. In other portions of the same region, in Wisconsin and Illinois, the two are more closely associated and are often found in alternate layers.

\section{SPECIAL DESCRIPTION OF THE MINES.}

The lead and zinc deposits of Iowa extend along the Mississippi for nearly eighty miles in the counties of Dubuque, Clayton and Allamakee.

The Dubuque area is by far the most extensive and important and has yielded a large proportion of the entire product of the state. Beginning at the valley of the Tete des Morts the metalliferous tract extends northwest to the Little Maquoketa. The diggings in the neighborhood of the former 
stream, however, were never very productive and have long since been abandoned. The Dubuque area proper is included between Catfish creek and the Little Maquoketa forming a belt from three to four miles wide and six miles long, with an area of some twenty square miles. The Galena limestone of this section has been deeply cut by the streams and is overlain in all its higher portions by the Maquoketa shales. Most of the shafts penetrate these shales for a greater or less distance before reaching the limestone sought. The number

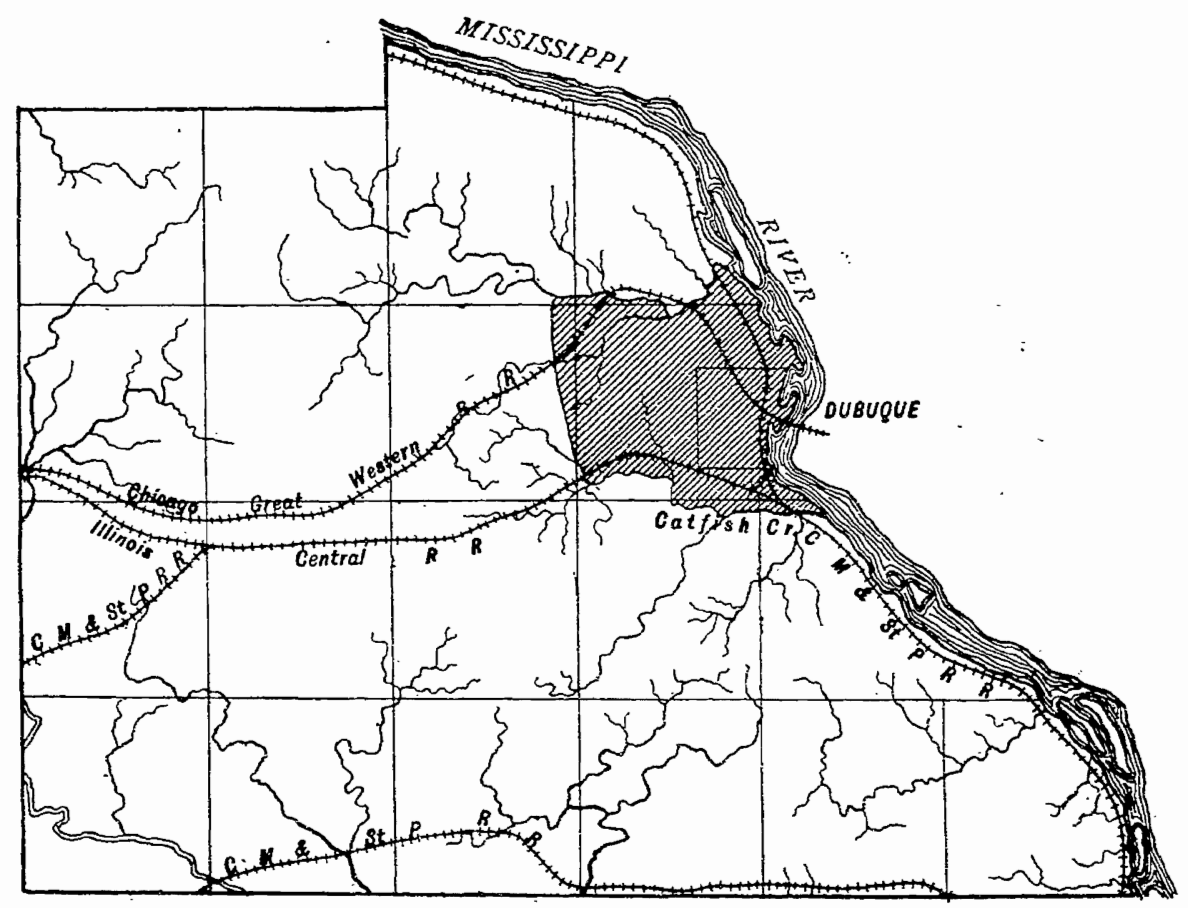

FIG. 11. Lead and zinc region of Dubuque county. The shaded area represents the productive region.

and size of the productive crevices included within this comparatively small area is very remarkable and it is probable that no other district of equal extent in the Mississippi valley has yielded so large an amount of ore.

Most of the mines are now being worked for zinc carbonate, or dry bone, and only a few are producing lead in any amount.

A special description of some of the more important and characteristic mines will serve to illustrate the mode of occurrence of the deposits and bring out more clearly their 
appearance. It is not claimed that the list is complete. Some of the most interesting mines were closed at the time the field work was done, and hence could not be visited. Other famous diggings have been worked out, or abandoned on account of the water, and are now inaccessible. For such reasons those which could be examined were comparatively few.

The first one selected for notice illustrates the occurrence of the zinc above the lead.

The Timber Range, or old "Ewing Diggings" at Durango, five miles northwest of Dubuque (Tp. 90 N., R. I E., Sec. 36, Se. qr.) was once famous for its Galena. The range has a width of 100 feet and is formed by three main crevices with

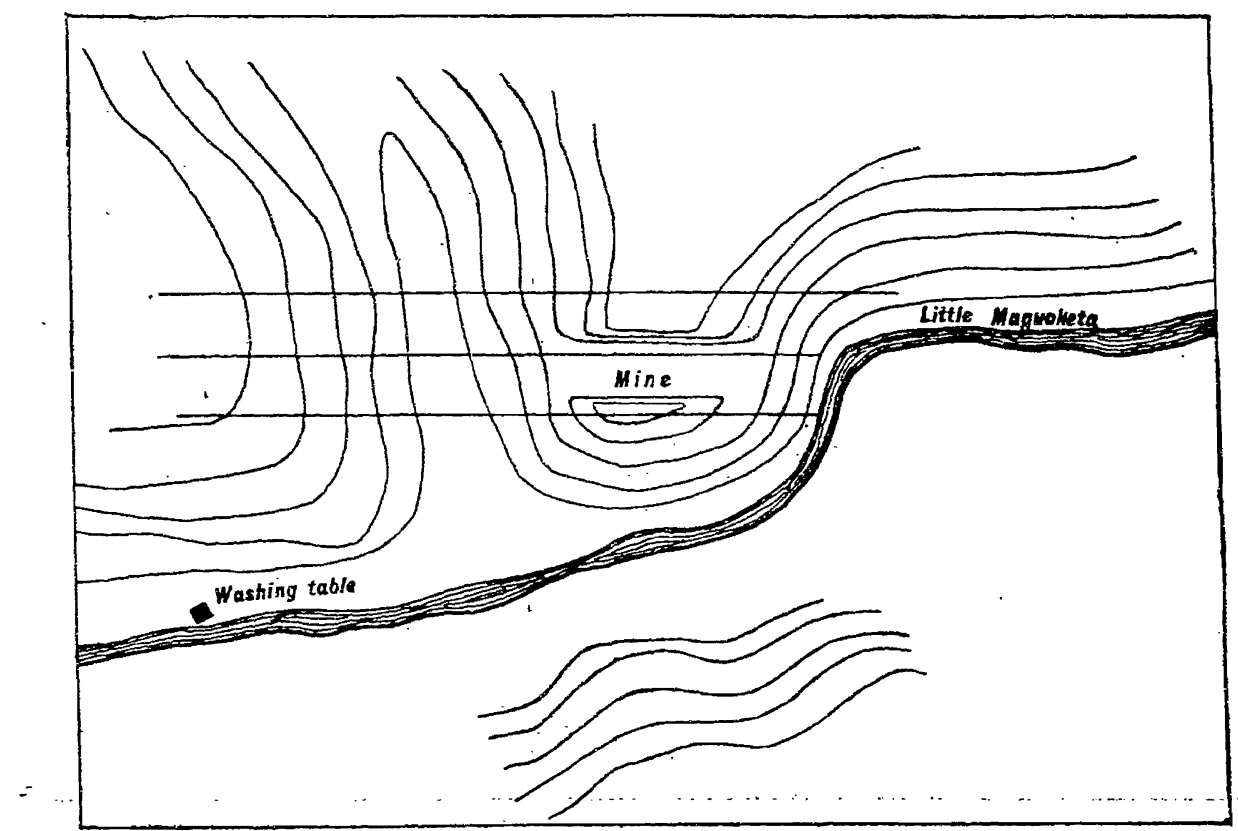

FrG. 12. Sketch showing Iocation of Durango zinc mine in hill above the Little Maquoketa. Three crevices represented.

a general direction $\mathrm{S} .80^{\circ} \mathrm{E}$. The openings occur ninety feet below the crown of the hill, and where they are enlarged the three fissures unite in caverns of immense size.

In these openings the lead occurred, and above them, extending to the surface, the hill is filled with zinc carbonate The zinc is known to extend also below the level of the lead. The mine is worked by means of an open cut extending 5 G Rep 
through the hill with a width of forty feet and a depth of about eighty feet. The crevices are more or less open up to the surface. Several can be seen in the face of the cut, and in them the ore is most abundant, though this is also found mixed all through the fractured limestone. The strata have been subjected to more or less strain, possibly owing to the large caves below, and are broken into fragments. The carbonate is found coating these pieces and filling the spaces between, occurring also, as stated, in the open crevices. The

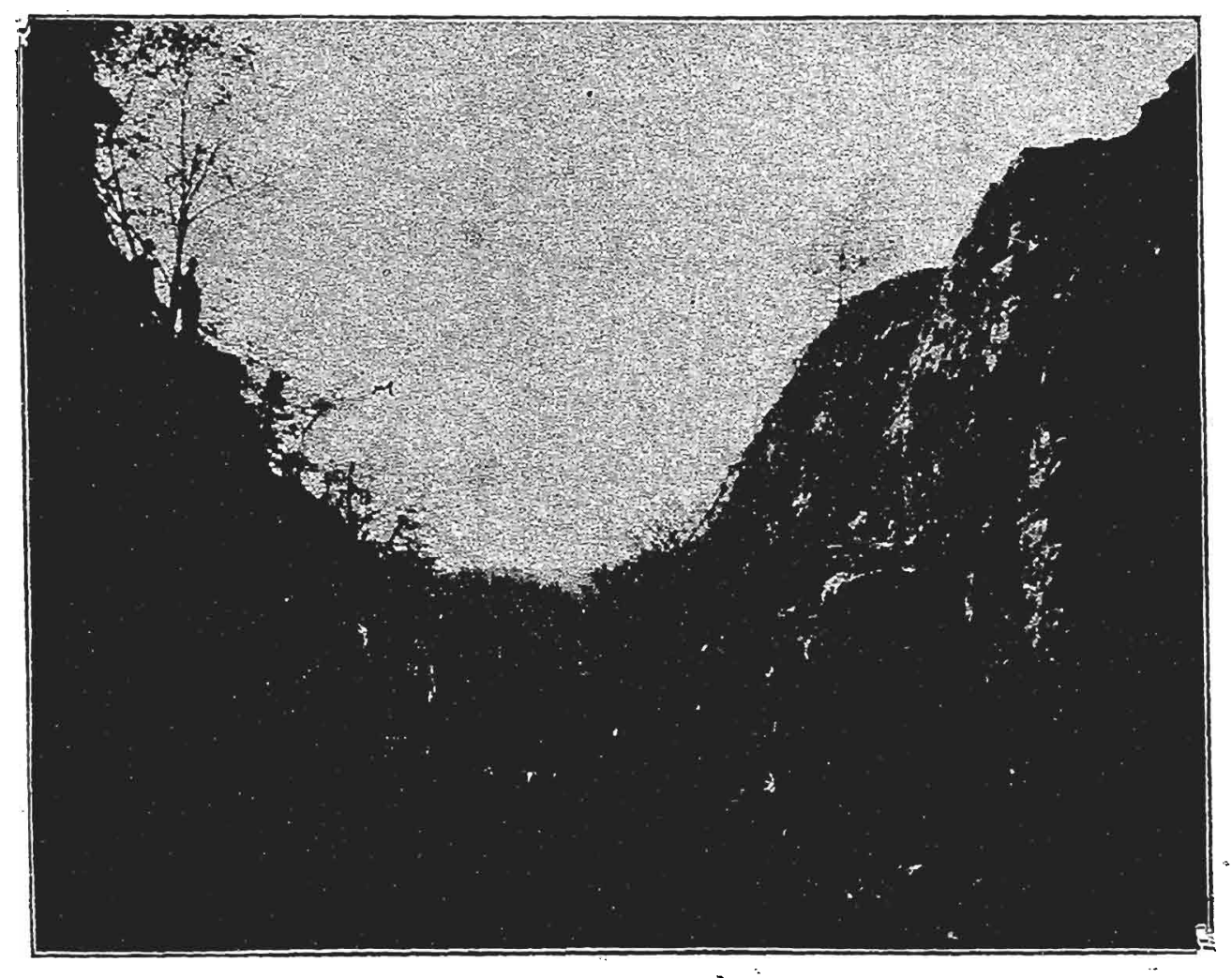

Frg. 13. Open cut at Durangó zinc mine.

latter where they appear in the cut, have a width of from one to two feet. In working the mine the larger masses are blasted, and the smaller ones loosened with the pick. The ore is removed from the rock, the latter is carted off to the dump, and the dry bone, mixed with more or less waste material, is carried to a neighboring stream. Here it is washed by an ingenious contrivance which thoroughly frees 
the ore from all sand and dirt. The method was invented by Mr. Goldthorp, superintendent of the mine, and is quite extensively used about Dubuque. An Archimedes screw, turned by horse power, revolves in a trough through which a stream of water is kept flowing. As the screw revolves it gradually works the ore up the gentle incline while the water runs down and carries with it all sand and dirt. Afterwards the dry bone is picked over by hand and the rock fragments thus separated. During the past season eighteen men were

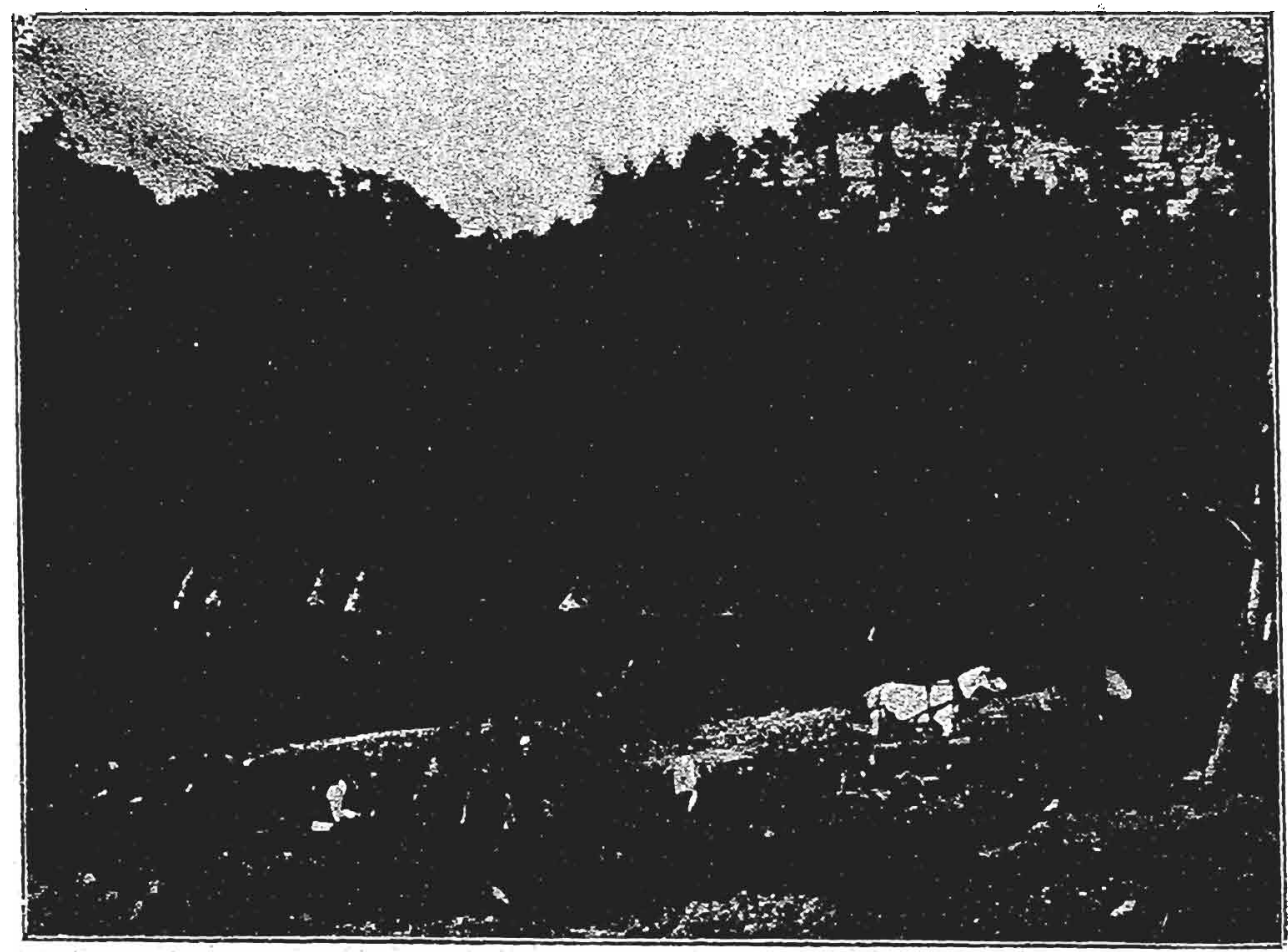

FIG. 14. Cleaning the ore from the Durango zinc mine.

employed at the mine and the daily output was from fifteen to eighteen tons of ore. This would mean a yield of over 2,500 tons for six months and is probably about the annual production of the mine for the last few years. The only zinc ore occurring in any amount at the Durango mine is the carbonate. Lead occurs in small amounts mixed with the zine, this being one of the two instances noted in which this phenomena appeared. 
Dubuque Lead Mining Company.-The mine of this company is located one mile west of Dubuque and has been worked for about one year and a half. It is on the west end of the old Level Range, which has been followed for nearly three miles and has yielded considerable ore from various points along its length.' At present (November, 1895) there are seventy-five men employed at the mine. The three shafts are 210 feet deep, with a steam hoist on one, and gins on the other two. The company have just erected a concentrator at the mine for the purpose of crushing and cleaning the ore. This was made necessary by the fact that in this mine much of the Galena occurs scattered through the rock, sometimes in particles of considerable size. The limestone is crushed and the lead then separated from it. The ore-bearing dolomite forms a zone from two to four feet wide and contains an abundance of iron pyrites. This latter mineral is often found here crystallized in beautiful octahedrons with a length of from one-fourth to three-fourths inches. Besides being disseminated through the rock the Galena occurs in large masses in what is probably the fourth opening, and it likewise fills the crevice above for some distance. The ore body is apparently an extensive one; 700,000 pounds of lead have already been raised. Work in this mine is made possible only by the constant operation of a steam pump which keeps the water below the opening where the ore occurs, and thus allows the miners to reach the deposit.

The Mc Gowen Crevice-Direction N. $86^{\circ} \mathrm{W}$. This crevice is located just west of Dubuque and was formerly operated for lead, but for the past eight years it has produced zinc ore. The shaft is 112 feet deep. Only the first of the openings present have been explored. The greater portion is above the cap rock and is called by the miners a "cap rock" opening. The expanded crevice is a large one, the average height being forty to fifty feet, and the width four to ten feet. In some portions it opens into caves with twice the above width, and these are filled with zinc ore mixed with clay and 
more or less rock, much as in the Durango mine. Some twelve feet west of the shaft the lead gave out and a few yards beyond zinc carbonate began to appear and soon occupied the entire opening. At one point almost the whole cavity is filled by the "keyrock," leaving only a narrow space on either side for the ore.

Wharton Crevice. - This mine has been operated for zinc twelve years. The shaft opens out into a large "cave" from which much lead was formerly taken. From this point the Galena pitched down toward the west and was fol-

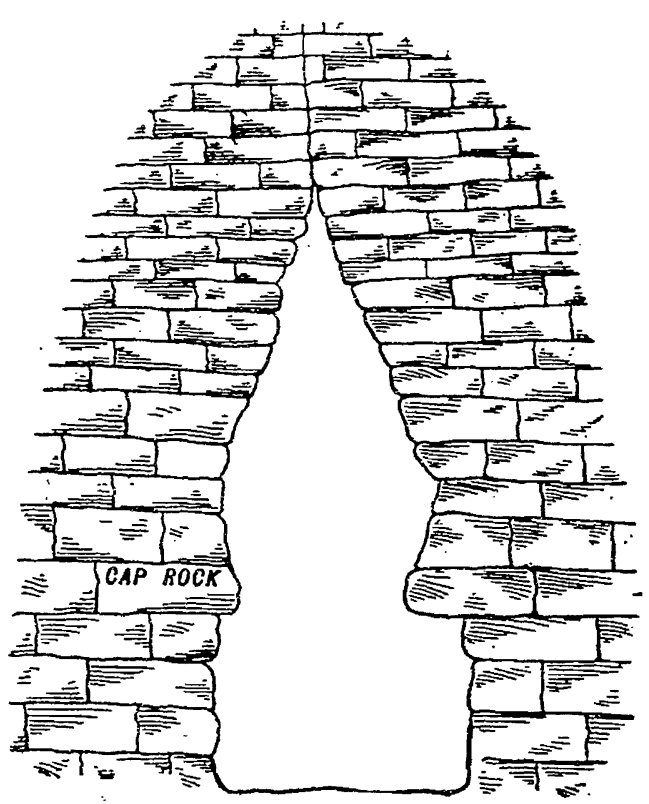

FrG. 15. McGowen crevice showing cap rock opening. lowed in the first opening for 150 feet. It then descended again to the second opening where it was followed 150 to 200 feet. Work was stopped at this point by water. The zinc is found in the upper opening above the section where much of the lead occurred, thus furnishing another example of the former ore occurring above the latter.

This crevice, like many in the Dubuque region, is extensive, being forty to fifty feet high by four to ten feet wide. In it, as in the McGowen crevice, occur many large caves which extend up into the "quarry rock." The crevice has been followed for over a mile west from the shaft.

Trueb, Southwell \& Co.-The mine belonging to this company is located in the city of Dubuque and has been in operation about nine years. It has yielded large quantities of zinc. It is worked by means of four or five shafts, one of which has reached a depth of 210 feet, being one of the deepest in the region. The mine has been closed for some time and cannot now be examined, but divers facts of interest were obtained from the owners and others. 
It is apparently an exception to the rule that the first opening is the largest, for here the second holds the place of honor, having a height and a width of forty feet. In it abound both the sulphide and carbonate of zinc, and the alteration of the blende into the Smithsonite can be traced in specimens collected here. In the first opening some Galena occurs with the zine, this and the Durango mine being the only ones in the state where the two ores exist together in this fashion. Between the shaft on Alpine street and the first one to the west, there is a bar that holds the water back. This extends in a general northeast and southwest direction and during part of its course is about under Nevada street. The water level west of this barrier is much higher than upon the other side. Thus in the Alpine shaft a depth has been reached seventy feet below the water level west of the obstruction.

Howe, Alexander de Seller's Co.-This mine, which is located at the corner of Eleventh and . Spruce streets, Dubuque, is a comparatively new one, having been operated only since March, 1892. The shaft reaches the first opening at a depth of eighty-five feet, and from this level alone has ore been removed. Drifts have been run east and west from the shaft, and only enough of the ore removed to give the miners room to work to advantage. The opening, while its dimensions have not been accurately determined, is known to be a large one and immense quantities of ore are in sight. Although, when visited, the mine had been worked only a little more than a year the drift had reached a length of about 800 feet, and 1,000 tons of zinc ore had been removed.

Kerrick Mine.-This mine, one of the largest and most productive in the district, is still being worked for lead. The crevice is almost an east and west one, having a direction $\mathrm{N}$. $89^{\circ} \mathrm{W}$. A pump has recently been introduced, and by means of it the water was so lowered that a body of ore in the second opening could be reached. Thus in fifteen days 317,000 pounds of Galena were raised, and in all, the mine is said to have yielded $20,000,000$ pounds. 
Passing north from the Dubuque area we find a few diggings about Sherrill Mound, three miles from Durango. They are the last met with in Dubuque county in this direction.

\section{CLAYTON COUNTY MINES.}

Lead has been mined in considerable quantities at two points in Clayton county-Buena Vista and Guttenberg. At Buena Vista a beginning was made in 1851 in Tp. 91 N., R. I W., Sec. 28, Ne. qr. Two nearly east and west ranges have been worked, and both are formed by three main parallel crevices with several minor ones. The ore in the south range occurred in

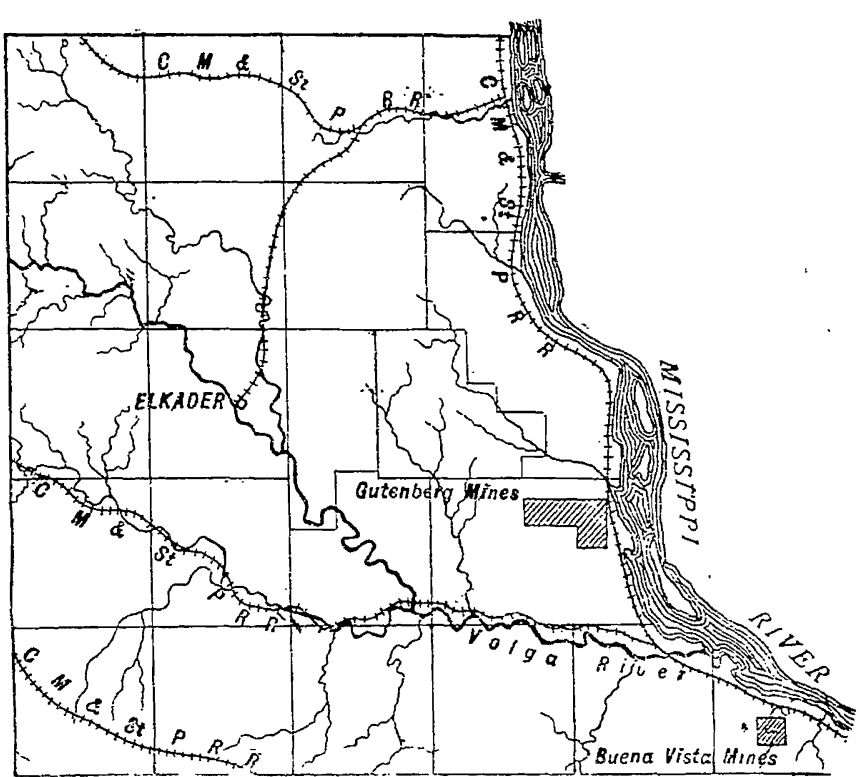

FIG. 16. Lead and zinc mines of Clayton county. a large body at the surface. The mine is on a side hill where the overlying strata have been eroded, leaving the deposit exposed. It was worked by an open cut and yielded lead in a generous measure. The crevice was followed 700 feet west of the ore body, but without further discoveries. The fissure is open up to the very surface, where it is from one to three feet wide, and is filled with clay and soil. One crevice in the north range has been worked by a level run into the hillside. Mining has been carried on here at intervals for over thirty years, and, although no record has been kept, the mine is known to have produced large quantities of Galena. Some zinc carbonate occurs in this same locality, but not in paying amounts. Several specimens of lead carbonate, Cerussite, were obtained here, and one of them analyzed by Prof. G. E. 
Patrick yielded 69.67 per cent of lead. It occurs only in small quantities and has been derived by alteration from the Galena. For many years little has been done in these mines, although some prospecting has been carried on from time to time. The deposits are met with lower in the Galena limestone than at Dubuque, but not at the base of the formation as at Guttenberg.

The Guttenberg mines are several miles northwest of the village of that name on Miner's creek, a small stream flowing into the Mississippi just below the town. The larger diggings were in Tp. 92 N., R. II W., Sec. 7, but there were others in section 18 of the same township and range, and still others in sections 11 and 12 , Tp. 92 N., R. III W. Both the Galena and Trenton limestones are here well exposed, the latter rising from 125 to 150 feet above the river. The higher hills are capped with 100 feet of Galena limestone. Miner's creek and its tributaries have eut deeply into both those formations, and the mines are located on the sides of the valleys which have in places cut across the east and west crevices. Work has been carried on almost entirely by means of tunnels or levels run into the hillside. The deposits here occur at the base of the Galena, at its junction with the Trenton. The ore is found in flat, comparatively wide openings, and is scattered through the crevice clay.

The Holmes mine is the largest in this district. The opening, which is in places fifty feet wide, was followed 2,000 feet. The cap rock forms a flat roof without fissure. The lead ore lay loose in the crevice material occupying the cavity, and was easily removed without blasting. Crossing the Holmes range was a "quartering," northeast and southwest, which was rich in ore. A north and south fissure close by also carried considerable amounts. The mineral in the Holmes, as not unfrequently occurs in the mines, "jumped" from one east and west to another parallel crevice of the same range. In this case the opening in the crevice followed became narrow and the Galena gradually disappeared, but only to 
reappear in the other crevice. In all the specimens seen from the Guttenberg district the lead crystallized not in simple cubes, but in combination forms of the cube and octahedron, the latter form often predominating or occurring alone. This locality formerly produced considerable lead, and two smelters were at one time in operation on Miner's creek. After a few years' working the deposits gave out in the majority of the diggings, and they are now practically abandoned.

Very little careful prospecting by experienced miners has been done in this region, the mineral having been hit upon almost by chance. Probably by careful and systematic search other ore-bearing crevices might be discovered.

\section{ALLAMAKEE COUNTY MINES.}

The only mine now being worked in this county is that of the Lansing Mining and Smelting Co., located five miles

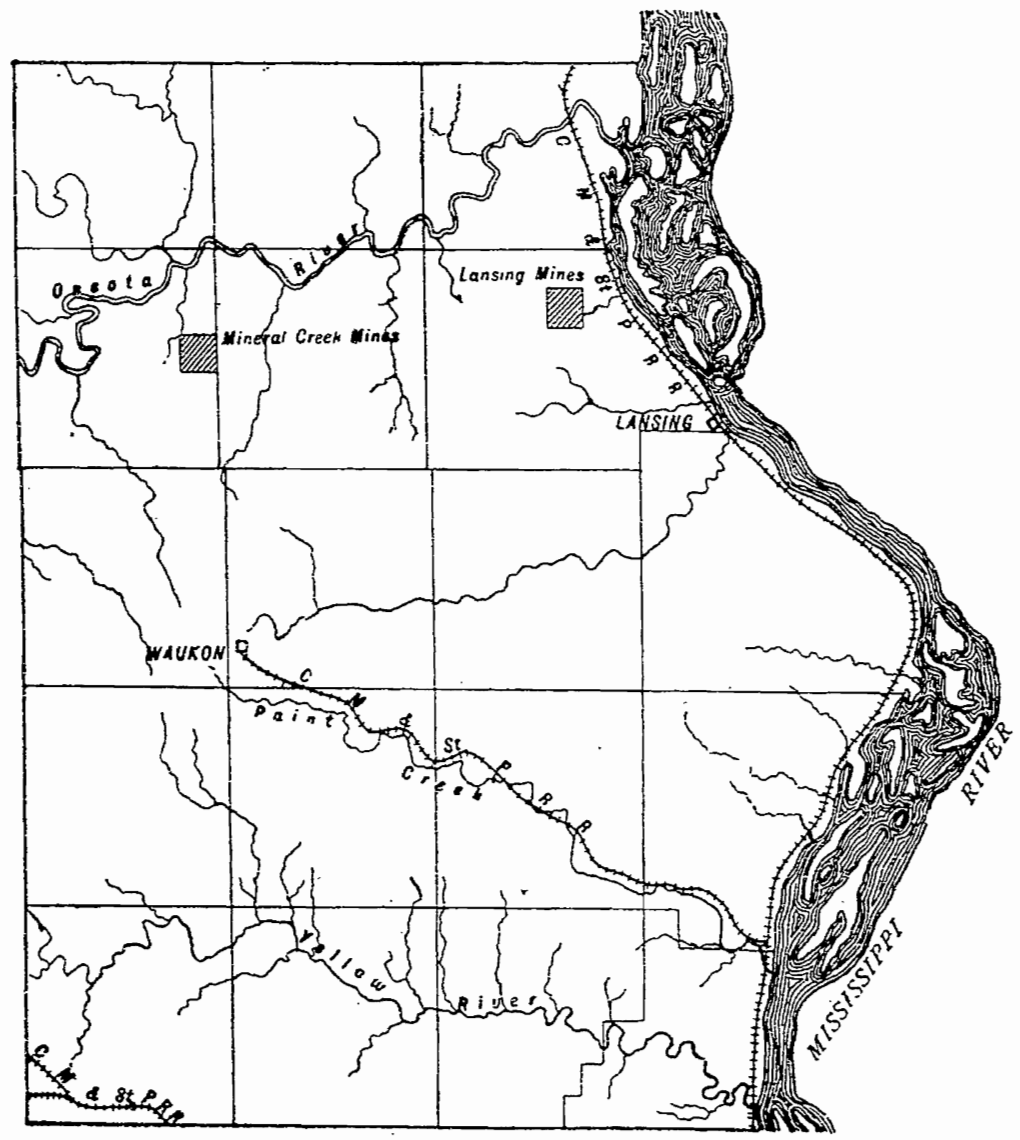

FIG. 17. Lead̄ and zinc mines of Allamakee county. 
northwest of Lansing in Tp. 99 N., R. IV W., Sec. 10, Nw. qr. This is of unusual interest on account of being in the Oneota limestone, in which ore had not previously been discovered except in small quantities. It was, indeed, considered practically useless to look for lead in this formation. Another remarkable fact in connection with this deposit is that it occurs as a vertical sheet in a north and south fissure. While these north and south crevices are not uncommon in the state, they are usually of limited extent and do not contain large bodies of ore. But here the sheet is an extensive

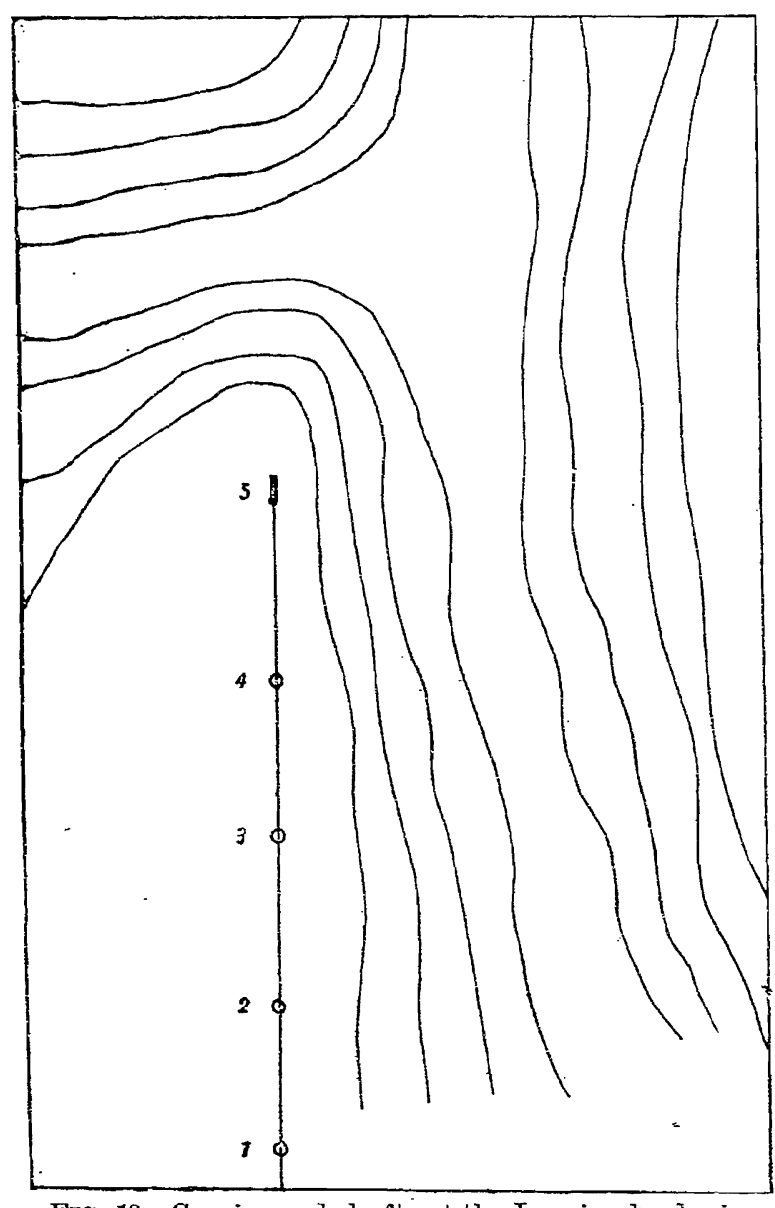

Frg. 18. Crevice and shafts at the Lansing read mine. one, and does not as yet show any signs of giving out. The mine was discovered in January, 1891, by Captain Turner, who had reached the conclusion that lead occurred in the Oneota, and had done considerable prospecting at various points.

The location is on a hillside that slopes to the north and east. While the general direction of the crevice is nearly north and south (S $10^{\circ}$ E.), its course is not straight but zigzags back and forth within certain limits, so that a shaft sunk on the general line of the fissure may be several feet out of the way. 
The sheet has been followed 1,000 feet and its limits have not been reached either to the north or south. At the north end of the present workings the fissure is interrupted by a ravine and the sheet thus outcrops. There is reason for supposing that it will be found again upon the other side. The main body of the sheet has a vertical extent of from twentyfive to thirty feet, and a width of from three to four inches. A shaft was sunk 113 feet to the Saint Croix or Potsdam sandstone, and Galena was found in small quantities downward to within four or five feet of the latter. The bulk of the ore is, bowever, about fifty feet above the sandstone.

The sheet of lead is either interbedded in the crevice clay or fills the entire space between the rock walls. Where it extends south under the hill and has been little exposed to weathering agencies, the sides of the fissure have not undergone decomposition and the sheet is in contact with the rock. In other places where examined an inch or so of clay was found between it and the limestone, the crevice in this case being from six to eight inches wide. Again, the fissure may open out until it has a width of three or four feet, and then be filled with

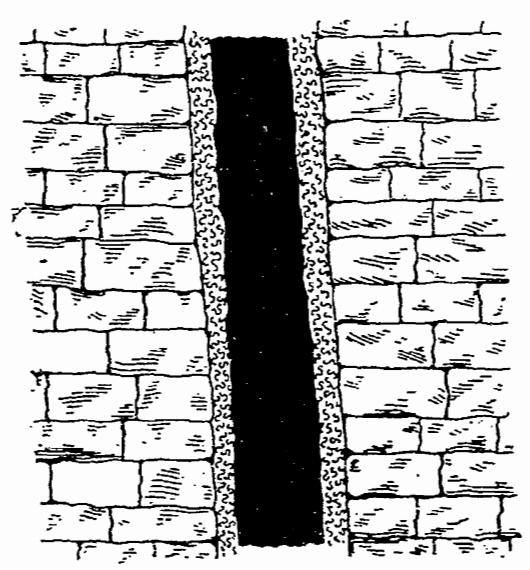

FIG. 19. Lead in vertical crevice between sheets of clay, Lansing lead mine. clay with the sheet of ore against the wall. In such a case the ore commonly lies against the east wall, or toward the lower side of the hill. The sheet does not extend vertically to the surface, but in the upper eight or ten feet curves over toward the east or down the slope. Evidently there has been a slipping of the hillside which has carried with it the top of the sheet, this bending being a result.

The mine has been worked by means of three or four shafts from thirty to sixty feet deep. From these, drifts are run in each direction at various levels, and thus the ore is removed. 
At the north end of the present workings a tunnel has also been cut along the side of the sheet.

Most of the ore is taken out in pieces of considerable size. The Galena is filled with many cavities, often lined with crystals of lead carbonate or Cerussite, formed by the alteration of the sulphide. One sample showed 80.55 per cent of lead. The ore contains nearly four ounces of silver to the ton. At the present time (November, 1895) the production has reached 500,000 pounds with excellent prospects for the future.

The following reference to the occurrence of lead in the Saint Croix is found in Professor Calvin's report on Allamakee county.*

"While the Oneota limestone is the lead-producing, and in general the lead-bearing rock of Allamakee county, some ore bodies are occasionally found in the underlying Saint Croix sandstone. The Saint Croix lead ore was doubtless deposited by descending waters that became charged with salts of lead while passing through the Oneota limestone and reached the Saint Croix before the sulphide was precipitated. Concerning one of these deposits very recently worked on the Lansing company's property Mr. Trewin writes: 'We took several thousand pounds from the Potsdam. (Saint Croix) sandstone, but there does not seem to be much yield in that tormation.' The ore body of the Saint Croix referred to by $\mathrm{Mr}$. Trewin lay in a fissure in the sandstone immediately beneath the lead-bearing crevice of the Oneota from which the Lansing Mining and Smelting Co. have taken practically all of the ore thus far produced. It occurred at the north end of the mine, where a ravine cuts transversely to the crevice, and all the ore contained in the sandstone was found within a hundred feet of the face of the bluff."

Lead was formerly mined at one other locality in Allamakee county, on Mineral creek (Tp. 99, R. VI W., Sec. 13), about two and one-half miles south of where it empties into the Oneota. Near the confluence of the two streams, a small

*Iowa Geol. Survey, Vol. IV, p. $10 \%$. 
town, New Galena, sprang up, and during the years 1856-57 prospecting and mining were actively carried on. The mines were in the upper part of the Oneota limestone,not far from its juncture with the Saint Peter sandstone. Mineral creek has cut its valley through this sandstone and well down into the underlying limestone which here has an exposed thickness of more than 100 feet. This latter rock shows evidence of considerable disturbance, being more or less brecciated, and has been recemented by siliceous material. It is full of cherty or flinty matter and is very impure.

The mines were on a hillside and were worked by means of short drifts. Instead of being in crevices the ore occurred scattered through the limestone, necessitating considerable blasting. None of the drifts extended more than forty to fifty feet from the surface as the mineral-bearing rock did not reach a greater depth. To separate the mineral great heaps were constructed with wood intermingled with the rock. These were fired, and after the fire had done its work, the heat was found to have been insufficient to melt the Galena: It had only broken the rock into small pieces. Then this was washed and the mineral was separated. The latter was smelted in a furnace located at the mouth of Mineral creek. During the two years that the mines were in operation sixty-three pigs were turned out and this trifling return represents almost the entire product of this district. When the locality was visited early in 1894 some prospecting was in progress, but with little chance of success. Float lead is found quite abundantly in the county, and the Oneota probably contains more or less of this mineral. But it is doubtful whether, as a rule, the ore occurs in well defined crevices and in amounts sufficient to make the mining profitable.

\section{ORIGIN OF THE ORE DEPOSITS.}

The question of the origin of the lead and zine deposits is one of much practical importance as well as great scientific 
interest. The subject has recently come into renewed prominence and has been ably discussed by Winslow, Jenney, Blake and others, all of whom are well acquainted with the -Mississippi valley deposits.

In treating of the genesis of these deposits it will be well to consider in the first place the original source of the lead and zinc and the manner in which the ores came to be confined to certain districts, and then to discuss the formation of the crevices and the deposition of the ore in these receptacles.

Original Source of the Lead and Zinc.-For the source whence the materials were originally derived we must doubtless look to the primitive Archean rocks forming the land mass to the north. As this was washed away and its materials carried into the Silurian sea, the waters became charged with metallic salts which were deposited along with the limestones. The chief agent in the precipitation of the metals appears to have been the organic life so abundant during this period. The death and decay of the vast multitudes of brachiopods, mollusks, and other forms gave rise to sulphureted gases. These gases were doubtless very effective in precipitating the metallic sulphides which were thus deposited along with the sediments.

Localization of the Deposits.- One fact in connection with these deposits is difficult of explanation on the theory of oceanic deposition; namely, the localization of the ore bodies. These bodies are confined to certain districts, outside of which the ground is nearly or quite barren, although as far as can be seen the conditions are quite as favorable. For example, the Dubuque mines are confined to an area of some twenty square miles, while to the north and south the Galena limestone carries no ore though everywhere cut by numerous crevices favorable for its reception. The same is true of the many mining districts of Wisconsin and Missouri. The mines are noticeably grouped about certain centers, while the surrounding country is unproductive. The natural supposition would be that the minerals were everywhere equally dis- 
seminated through the rock and that they have been leached out and deposited in the fissures only in certain favorable localities. But this is hardly probable in view of the fact that the conditions are apparently just as favorable for the formation of ore bodies in the barren districts as in the productive ones. How then can the localization of the deposits be accounted for on the generally accepted theory that the lead and zinc were contained in the oceanic waters and were distributed through the rocks at the time of their formation?

Prof. J. D. Whitney, * over thirty years ago, published an elaborate report on the lead region and discussed at considerable length the origin of the deposits. His views differed quite radically from those of Messrs. Owen and Percival, who had. maintained that the metals were derived from great depths. Professor Whitney was the first to advance the theory that the metallic salts were held in solution in the waters of the ancient sea, and were thrown down by organic matter or the sulphureted hydrogen arising from its decay. But no satisfactory explanation was given for the localization of the lead and zinc.

Professor Chamberlain t attributes the original concentration of the deposits to the currents of the old Silurian sea. The oceanic waters impregnated with metallic salts derived from the leaching of the adjacent lands were borne by currents to areas where there was an abundance of organic life, and here the metals would be extracted and thrown down along with the sediments.

Mr. Arthur Winslow $\neq$ has recently advanced a somewhat different hypothesis concerning the origin of the Missouri ore bodies. He holds that the concentration is due to the surface decomposition of the rocks. "According to our theory the concentration is entirely secondary. It is primarily a result of great and long-continued surface decay of the rocks; and secondarily the result of the presence of local

*Geology of Wisconsin, 1862.

+Geol. Wisconsin, Vol. IV, p. 52, $188 \%$.

¥Missouri Geol. Surv., Vol. VII, p. 477. Jefferson City, 1894. 
favorable physical and chemical conditions." The hypothesis starts with the proposition that the minerals existed in the "Archean rocks, and with the decay of these became diffused through the later formed sediments. It will be noticed that this theory agrees with that of Chamberlain in recognizing the presence of the minerals in the country rocks and the derivation of the deposits from them; but it differs in maintaining a condition of general diffusion, rather than one of concentration over certain favored areas.

The evidence is abundant that very extensive sub-aerial decay has befallen the rocks in the Missouri region, and during successive geological periods many hundreds of feet have been removed. Mr. Winslow believes that in the WisconsinIowa area the same processes were long operating to concentrate the ores. It has already been stated that the district is unglaciated, and thus has long been exposed to atmospheric agencies by which the rocks were extensively decomposed.

Mr. W. P. Blake, * who is familiar with the Wisconsin deposits, seems to hold something of the same view as Winslow, if we may judge from the following words: "The evidence is strongly in favor of the view of the long-continued decomposition, downward flow and recomposition of not only the ores of zinc but of lead and of the pyrite from the upper formations to the lower, as the general water-level of the region subsided and as the upper formations by long continued exposure through geologic ages were gradually decomposed in place. By such a process the present zinc deposits would seem to have accumulated and to represent the originally diffused ores in many formations, possibly as high in the geologic scale as those of Missouri, or the Lower Carboniferous. This is, however, improbable owing to the dense and impervious nature of the intervening Hudson river (Maquoketa) shales." It would seem that this impervious character of the shales constitutes a serious objection to Winslow's theory as applied to the Iowa deposits. The ore-

\footnotetext{
*Trans. Am. Inst. Ming. Eng., Vol. XXII, p. 621. New York, 1894.
} 
bearing beds are commonly overlain by these shales and ore occurs mostly near the top of the Galena limestone. Granting that the overlying Niagara and Maquoketa formations were impregnated with lead and zinc, it would hardly have been possible for these to make their way in solution through the impervious shales. In other words there could not have been in this area a very extensive downward flow and re-composition of the ores. The process has doubtless been going on within the Galena formation itself and may have caused some local concentration, but the limestone has not undergone very extensive decomposition in situ, and the ore is found largely in the upper beds.

For these reasons, while Chamberlain's theory of ocean currents may appear somewhat too hypothetical, it furnishes on the whole the most plausible explanation yet offered for the localization of the Upper Mississippi deposits.

Formation of the Crevices. - Cavities and crevices in the rocks are formed in several different ways. They may result from contraction due to solidification, drying or cooling. A familiar example of this process is seen in the cracks found in basalt. It is probable that some of the joints of sedimentary rocks have had the same origin.

But the most important cause of fracture is found in the movements of the earth's crust, producing a folding and crumpling of the strata. When such anticlinals and synclinals are formed, the rocks are fissured by the strain to which they are subjected. Should the walls of the fissure slip over each other, one side being raised or lowered, a fault would result. The fractures, when once formed, become the channels for subterranean drainage, and thus are enlarged and modified by the dissolving power of water.

The crevices of the Upper Mississippi region are apparently due to the second cause. Extending east and west through the lead district are numerous undulations of the strata. These flexures were doubtless the chief agent in the production of the crevices. As the strata were slowly 6 . G Rep 
elevated the heavily bedded limestones were fissured in a direction parallel to the axis of elevation, and crevices more or less open were formed. In a direction at right angles little force was exerted, and the beds were simply fractured, produeing the narrow north and south fissures. It is also possible that the latter may be due to the contraction of the rock as it solidified.

It is to be noted that the ore deposits of this region do not occur as fissure veins of indefinite extent in depth, but are what are known as "gash veins" of limited extent and confined to one rock series.

Filling of the Crevices. - Two opposite views are at present held concerning the source from which veins have derived their metalliferous contents. (1) It is claimed on the one hand that the minerals have been deposited from hot solutions rising through fissures from profound depths. The solvent power of such waters would be great on account of the temperature and pressure, and they would thus be rich in mineral materials which would be deposited on cooling, or on relief from pressure. This is the view so ably advocated by Professor Posepny in his recent paper on the "Genesis of Ore Deposits," " and it has among its supporters many eminent geologists and mining engineers. (2) Opposed to this ascension theory is that of lateral secretion, according to which the contents of the vein are derived from the wall rock itself, instead of from unknown depths. A broad interpretation of this theory does not necessitate the derivation of the minerals from the rock directly bounding the vein, but admits that they may have been leached out from a considerable distance on all sides. It supposes that there is a free circulation of surface water through crevices and porous strata, and consequently a ready transfer of solution would result. These waters may traverse the rocks in any direction, and may thus in some cases rise and be said to come from below. Or again, they may flow into the crevice either

*Trans. Am. Inst. Ming. Eng., XXIII, p. 197. New York, 1894. 
from the sides or from above. This broad conception of the lateral secretion theory has much in common with the one first named. But it differs from that, however, since it does not necessitate the presence of profound fissures or faults, nor the rising of the heated waters through these from great depths.

A third view as to the origin of ore deposits is mentioned by Professor Kemp.* It is held by a number of careful observers and was brought into prominence by Emmons $\dagger$ in his report on the Leadville region. According to the replacement theory, as it is called, no large cavity is supposed to have previously existed. There is a circulation of ore-bearing solutions which interchange their metallic contents, molecule by molecule, for the substance of the rock. The ore body in this case has no well defined limits but shades off gradually into the barren country rock.

We are now ready to inquire which one of the above theories explains in the most satisfactory way the source of the Iowa deposits. There seems to be little doubt that to the process of lateral secretion is due the deposition of the ores in the crevices and that they have thus been derived from the limestone whence they have been leached by surface waters.

The view that the metal-bearing solutions came from below is strongly advocated by. Professor Jenney $\ddagger$ who holds that the Mississippi valley ores have been deposited by hot waters rising through fissures.

But there are numerous objections to this theory as applied to the region under consideration and among them may be mentioned the following: (1) No true fissures extending to great depths have been discovered. (2) Faults are of rare occurrence, and where they are occasionally found have no apparent connection with the deposits. (3) The ores exist only in comparatively small amounts in the underlying Saint

\footnotetext{
*Ore Deposits of the United States. New York, 1895. tThe Geology and Mining Industry of Leadville, with atlas, Monograph XII, U. S. Geol.
Surv., Washington, 1886.

The Lead and Zinc Deposits of the Missisșippi Valleỵ: Trans. A m. Inst. Ming. Eng., Vol.
XXII, p. 171. New York, 1894.
} 
Peter sandstone and Oneota limestone, and are almost altogether absent from the Saint Croix or Potsdam formation.

On the other hand there are many facts connected with the mode of occurrence of the ores which go to prove that the waters came from above. Masses of Galena are frequently found suspended from the roof of the openings. These could only have been formed by waters that reached the crevices from the upper strata. A few miles soutb of Dubuque crevices are met with identical in every respect with the orebearing fissures farther north, but instead of carrying lead and zinc, except in small amounts, they are decorated with great numbers of stalactites and stalagmites. The ore deposits of the region have evidently had the same origin as these lime formations, and no one questions the fact that the latter are due to moisture trickling down from above.

In order that the theory of lateral secretion may be well established it must be shown that the metals are diffused through the country rock. The necessary analyses have not been made for the Iowa region, but Winslow in his lead and zinc report" shows that the limestones and crystalline rocks of Missouri do contain small quantities of these minerals.

"The amounts of metallic lead vary from about .0004 to .007 per cent, of metallic zinc from about .0002 to .018 per cent, and of copper, magnese and barite there are correspondingly small amounts. It thus appears on this hypothesis, which does not require that the ores should come from the immediately adjacent wall rocks, that the metalliferous contents of the country rocks are ample to supply the ore deposits."

There is every reason to believe that the Galena limestone of Iowa also contains small quantities of lead and zinc, and that these have been leached out by percolating waters and deposited in the crevices.

It is not uncommon to find small particles of Galena or sphalerite in the different limestone formations of the state.

* Missouri Geol, Surv., Vol. VII, p. 478. Jefferson City, 1894. 
In the Oneota small pockets of lead are very common and denote the presence of this mineral in considerable abundance.

\section{GENERAL METHODS OF WORKING THE MINES.}

In working the mines the very simplest methods are used. Expensive machinery has never been employed in the Iowa region. Only a few of the shafts have reached a depth greater than 200 feet, and the majority are less than this. The most common method of hoisting the ore is by means of the windlass. In the larger mines, however, it is customary to use a gin. The latter consists of a large wooden drum, six to eight feet in diameter, which revolves in a horizontal plane and is turned by horse power. The only steam hoist in the Dubuque district is the one recently put in by the Dubuque Lead Mining Co. The same company has a steam pump in operation in their mines, by means of which the water has been lowered so that ore is being taken from one of the deeper openings. As already stated the Durango zinc mine is worked by an open cut. The ore is loaded directly into the wagons as it is removed and is taken down to the neighboring stream and washed as described above. Some of the mines, such as those at Guttenberg, have been worked by means of drifts run into the hillside but in the great majority of cases the openings are reached by shafts.

\section{STATISTICS.}

The following is a list of the principal lead and zinc mining companies of the state:

Dubuque Lead Mining Co., A. W. Hosford, president; E. T. Goldthorp, superintendent.

Lansing Mining \& Smelting Co., J. H. Trewin, president.

Dubuque Zine \& Lead Mining Co., E. T. Goldthorp, superintendent.

The four companies which follow, own and operate zinc mines in the city of Dubuque: 
Trueb, Southwell \& Co.; James Hird \& Son; Howe, Alexander \& Sellers Mining Co.; Dexter \& Hird.

Royce \& Co., and the Key City Co., are operating mines near Dubuque.

Most of the zinc mines have been closed for nearly two years on account of the low price paid for carbonate, the average being only $\$ 5$ to $\$ 6$ per ton the past year. About 800 tons were, however, sold at these figures. There are very large quanties of ore in sight in these mines as even a brief inspection clearly shows, and they are capable of yielding thousands of tons for some years to come.

All the zine carbonate from the Iowa mines is bought by Mineral Point, Wisconsin, smelters, where it is used in the manufacture of paint. The price of the ore has advanced somewhat within a few months with prospects of: a still further rise. Until the past year or two the dry bone has brought from $\$ 12$ to $\$ 18$ per ton, according to the quality.

Most of the lead from the Dubuque district is sold to W. G. Waters, who has a smelter a short distance south of the city. The lead from the Lansing mine is sent to Chicago to be smelted. The price of lead is also low at present, mineral which formerly sold at $\$ 20$ to $\$ 22$ now bringing only $\$ 17$ per thousand pounds.

The output of the Iowa mines for the past year (1895) can be given only approximately. They have produced about 750,000 pounds of lead ore and from 3,000 to 3,500 tons of zinc. But it must be remembered that most of the zinc mines have been closed during the past two sersons. They are easily capable of yielding from 8,000 to 10,000 tons of ore annually. 

